Chapter 4

\title{
Weed Seed Rain Dynamics and Ecological Control Ability in Agrophytocenosis
}

\author{
Vytautas Pilipavičius \\ Additional information is available at the end of the chapter \\ http://dx.doi.org/10.5772/55972
}

\section{Introduction}

Evolving together with agricultural plants, weedshaveadapted theirgrowth and biologicalcycle of development. The dispersal of weed seeds in agriculture fields is increased by current grain harvesting technology after seed set [1,2]. Herbicides are used to prevent new weed seed bank additions. Although herbicides cannot control all weeds, they may partially control them, thus weeds ripen fewer seed numbers. Therefore, infest soil, straws and awns by seeds [3]. Intensive use of herbicides following the traditional crop growing technologies, however, does not entirely solve the problem of weediness [4].Surviving weeds after herbicideapplications are able to produce new seeds [6], depending on species, significantly decreasing total seed production [5]. Even a few weed plants left undamaged by herbicides can produce considerable weed seed amounts [7]. Previous research of Leguizamon and Roberts (1982) revealed that after cultivation in early April of a sandy loam soil with 9500 apparently viable seeds $\mathrm{m}^{2}$ in $0-10 \mathrm{~cm}, 295$ seedlings $\mathrm{m}^{2}$ emerged, of which about half survived to maturity in July. Seeds were dispersed from mid-June to November and 136,460 $\mathrm{m}^{2}$ were returned to the soil, representing a 14-fold increase in the seed bank. Application of soil-active herbicides reduced the numbers of weeds and the total seed output, but that of tolerant species was increased. Maximum numbers of seeds were $59,980 \mathrm{~m}^{2}$ for Chenopodium album, 39,430 $\mathrm{m}^{2}$ for Stellaria media and $37,580 \mathrm{~m}^{2}$ for Veronica persica [8]. Today more attention is given to ecological problems which arise through use of herbicides [9]. Pesticides are leaching through the soil and into groundwater far more commonly than the projected ones a decade ago. Point sources may be widespread but are not the sole cause; it is also clear that many pesticides are leaching to groundwater from routine, nonpoint source labeled use. Controlled plot studies show the intermittent, often rapid delivery of many pesticides to shallow groundwater. Generally, the concentrations of pesticides in groundwater are low, in the $0.1-5.0 \mu \mathrm{g} \mathrm{L}^{-1}$ range. Even at these concentrations there are concerns for longterm, chronic exposure to a large segment of the public through drinking-water supplies [10]. 
According to Seralini et al. (2012) agricultural edible GMOs and formulated pesticides must be evaluated very carefully by long term studies to measure their potential toxic effects. First longterm research study "Long term toxicity of a Roundup herbicide and a Roundup-tolerant genetically modified maize" showed worrying results in rat pathology (tumor development, liver congestions and necrosis, etc.). The experimental object in this study was Rounduptolerant genetically modified maize (from $11 \%$ in the diet), cultivated with or without Roundup, and Roundup alone (from $0.1 \mathrm{ppb}$ in water) [79]. In recent years ecological and economic factors provided a need and a necessity to decrease the use of herbicides or even to refuse them entirely [11]. Research and policies to resolve the problems of agricultural impacts on the environment will require a new focus on integrated farm-management systems that enhance efficiency and reduce off-site impacts [10]. The quality of weed control in today's agriculture depends on the ability to eliminate seeds, which are still in the soil and to limit the amount of additions [1,12], aswellintegratingnon-chemical-ecologically acceptable-weed controlmeans.

The research hypothesis: most weed seeds ripened in the crop would be removed from the field together with spring barley harvested in the late milk-early dough growth stage of maturity. Accordingly in the late milk-early dough growth stage spring barley maturity, the highest dry matter yield and energy is accumulated. The aim of this work was to evaluate weed seed rain dynamics, and implications on ecological and economic management.

\section{Evaluation of spring barley agrophytocenosis}

Field experiment site and soil type. A field experiment was conducted at $54^{\circ} 52^{\prime} \mathrm{N}$ and $23^{\circ} 49^{\prime} \mathrm{E}$. The soil of the experimental site is Calcari-Epihypogleyic Luvisols - LVg-p-w-cc drained clay loam on sandy light loam. The soil agrochemical characteristics: $\mathrm{pH}_{\mathrm{KCl}} 7.08-7.25$, humus $2.22-2.45 \%$, mobile $\mathrm{P}_{2} \mathrm{O}_{5}-245.0-251.3 \mathrm{mg} \mathrm{kg}^{-1}$ and mobile $\mathrm{K}_{2} \mathrm{O}-93.6-110.5 \mathrm{mg} \mathrm{kg}^{-1}$. Agrochemical soil properties were established using the infrared ray system PSCCO/ISI IBM - PC 4250. Soil samples for agrochemical analysis were taken from $0-20 \mathrm{~cm}$ soil layer from 10 sites of all treatments and their replications, making combined samples.

Experimental design. The experiment was arranged as a randomized complete block design with treatments including the following harvest timing, which was made on the basis of spring barley maturity stages by Zadoks [13] and Meier [14].

Spring barley was harvested at the stages of maturity:

1. Stem elongation $39-41 *, 37-39,31$

5. Late milk-early dough 77-83, 77-83, 77-83

2. Heading 57-59, 55, 57-59

6. Dough $87,85,87$

3. Early milk 71-73, 69-71, 69-71

7. Hard $92,91-92,92$

4. Milk (medium milk) 75, 73-75, 73

* - decimal code for spring barley development during experimental years: 1997, 1998 and 1999. 
Experimental treatments were replicated four times. Total size of each experimental plot was $96 \mathrm{~m}^{2}(4 \times 24 \mathrm{~m})$ and results recording plot size $-66 \mathrm{~m}^{2}(3 \times 22 \mathrm{~m})$.

Spring barley growing conditions. The preceding crop for spring barley was winter wheat Triticum aestivum (1997), spring barley Hordeum vulgare (1998) and cultural amaranth Amaranthus spp. (1999) [1]. In every year of the experiment, double-row barley cv 'Roland' was grown on different fields. Herbicides were not used in the experimental field for evaluation of alternative weed control. Complex phosphorus, potassium and nitrogen fertilizers $(60 \mathrm{~kg}$ ha ${ }^{-1}$ of active compounds) "Azofoska" (N:P:K ratio 1:1:1 by 16\%) were applied on spring barley in spring after sowing before sprouting. Soil tillage in every year of the trial was the same. Each year, mouldboard ploughing at approx. $24 \mathrm{~cm}$ depth was accomplished in September. Autumn and spring loosening at approx. $8 \mathrm{~cm}$ depth was performed in October and April respectively, while spring loosening with harrow at approx. $4 \mathrm{~cm}$ depth was accomplished in early May, just prior to crop sowing.

Spring barley productivity. At stem elongation, heading, early milk, milk (medium milk) and late milk-early dough growth stages of maturity spring barley was harvested by frontal reaper for biomass and at dough and hard stages by combine harvester for grain.

Whole-plant silage was prepared from spring barley biomass harvested at early milk, milk (medium milk), late milk-early dough and dough stages of maturity. Spring barley green biomass was chopped up with the grinding-mill and ensiled in $3 \mathrm{~L}$ volume glass jar taking into account method used by Wilson and Wilkins [15].

Laboratorial analyses of spring barley whole-plant biomass, grain and silage: dry matter, crude protein, crude fat, crude fibre, crude ash [16] and metabolizable energy for ruminants (cows) in $\mathrm{MJ} \mathrm{kg}^{-1}$ of dry matter [17] were determined at each harvesting growth stage in prepared samples for analyses. Drying plant samples at $103^{\circ} \mathrm{C}$ for 4 hours, there was established the amount of dry matter and burning at $550^{\circ} \mathrm{C}$ for 3.5 hours in muffle-furnace, there was established the amount of crude ash. Crude protein was established by the Kjeldahl method and crude fat by direct extraction with petrol-ether for 6 hours in Sokslet device. The concentration of crude fibre was established by plant samples boiling with adequate concentration of sulphuric acid and potassium alkali, filtered, separated, washed, dried, weighed and burned at $500^{\circ} \mathrm{C}$ for 3 hours in muffle-furnace [16]. Metabolizable energy [ $\mathrm{MJ} \mathrm{kg}^{-1}$ ] in dry matter of fodder for ruminants (cows) was established depending on gas production $\left(\mathrm{CO}_{2}\right.$ and $\left.\mathrm{CH}_{4}\right)$ in vitro and fodder chemical composition, by the Hohenheim fodder value test. $200 \mathrm{mg}$ of fodder sample with cow rumen fluid, micro- and macro-elements, buffer- and reduction-solutions is placed in the special test-tube and incubated in a rotary thermostat by $39^{\circ} \mathrm{C}$ for 24 hours [17]. Silage fermentation analysis was made according to standard methods used in Agrochemical centre of Lithuanian institute of agriculture. It evaluated silage $\mathrm{pH}$, concentrations of lactic, acetic and butyric acids.

Crop weediness. Weed samples were taken at the early milk stage of spring barley maturity. There were 10 samples taken from every experimental plot by wire frame of $20 \times 30 \mathrm{~cm}$. Airdried weeds were divided into species, counted and weighed. 
Weed seed rain. Dynamics of weed seed rain in spring barley agrophytocenosis was established according to Rabotnov [18] method and other weed seed rain experiments [8, 19, 20]. Fifty troughs were laid out in each of four replications, in chess-order, in tens (Figure 1 and 2). In total, two hundred troughs were used. Weed seeds from the troughs were collected every 2-4 days. The collected seeds were divided into species and counted.

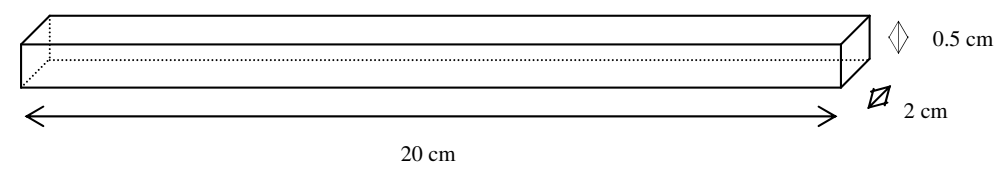

Figure 1. Schema of trough used for the weed seed rain establishment [1]

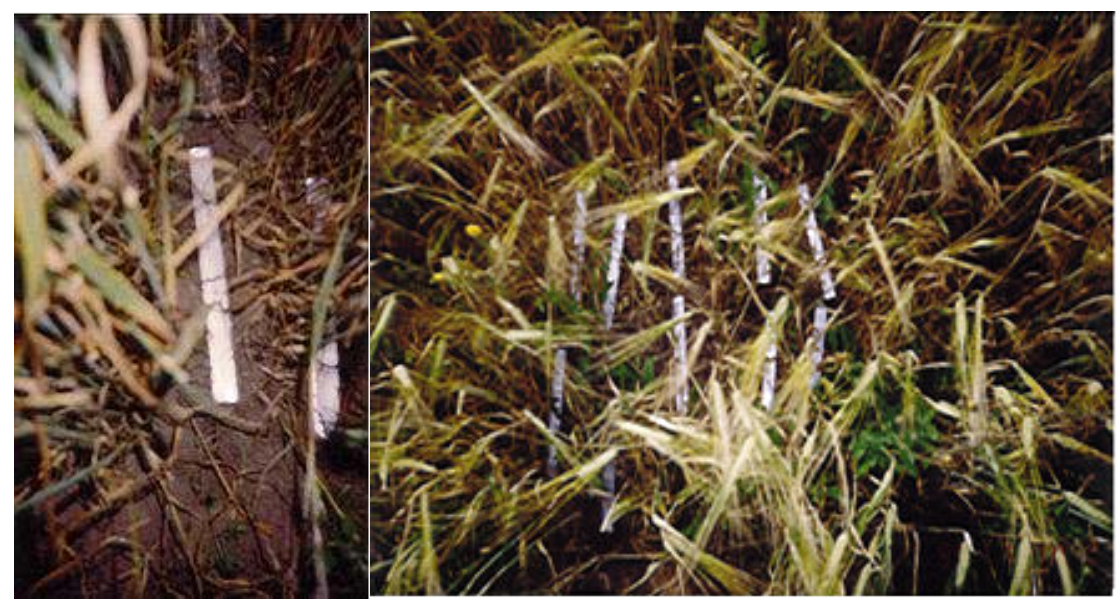

Figure 2.Troughs for collecting weed seeds in spring barley crop, photographs by Vytautas Pilipavičius

Meteorological conditions. The Lithuanian territory occupies intermediate geographical position between west Europe oceanic climate and Eurasian continental climate. The climate of the Lithuanian territory forms in different radiation and circulation conditions. Differences in these conditions hardly cross the boundaries of microclimatic differences; therefore, Lithuania belongs to the western region of the Atlantic Ocean continental climatic area [21]. Meteorological conditions during experimental years were established utilizing data of Kaunas (Noreikiškès) meteorological station situated in vicinity of the experimental fields. Meteorological factors taken included: average air temperatures, sum of active air temperatures (> $\left.10^{\circ} \mathrm{C}\right)$, rainfall $(\mathrm{mm})$ and sunlight duration in hours.

Economic treatment evaluation. In order to evaluate the economics of alternative and conventional harvest technologies the valuations of agricultural machinery were used [22-24]. The price of fodder spring barley is evaluated in $320 \mathrm{Lt} \mathrm{t}^{-1}$, and the normative price of straws in 27 
$\mathrm{Lt} \mathrm{t}^{-1}$ [the ratio of national currency Litas $(\mathrm{Lt})$ and Euro $(€)$ is $1 €=3.4528 \mathrm{Lt}$ ]. The value of spring barley biomass at the late milk-early dough growth stage of maturity was determined according to the energetic value of its grains and straws. Calculating the costs of spring barley harvested at the late milk-early dough growth stage of maturity includes autumn soil ploughing, autumn and spring continuous cultivation and cultivation with harrowing, sowing, green biomass pressing into rolls and their rolling with pellicle as well as transporting were evaluated. Calculating the costs of spring barley harvested at the hard stage of maturity includes autumn soil ploughing, autumn and spring continuous cultivation and cultivation with harrowing, sowing, as well as the cereal harvesting, grain and straw managing were evaluated. The tractor MTZ-80/82, the cereal harvester SK-5 "Niva“ as well as various agricultural machinery were used for these proceedings.

Statistical data assessment. The research data were statistically evaluated by dispersion analysis ANOVA method applying Selekcija $[25,26]$ and SigmaStat [27] software packages. Degrees of phenomena interdependence and their directions were established by correlation-regression analysis applying SigmaPlot software package [28]. Reliability of dependencies was evaluated by the $p$ criterion.

\section{Weediness of spring barley agrophytocenosis}

The field experiments were carried out in separate fields with different weed infestations (Table 1). The experiment initiated on a very weedy field. The second year of the experiment trial was moved to the field where weed density was established more than three times and weed air-dry biomass was 2.6 times less comparing with the spring barley agrophytocenosis of the first year experiment. During the experiment in 1999 weed density was 135 weeds $\mathrm{m}^{-2}$, i.e. analogically as in 1998 but their air-dry biomass was more than 6 times less and weighed only $18.9 \mathrm{~g} \mathrm{~m}^{-2}$. During the three year experiment in spring barley agrophytocenosis, annual weeds dominated accounting for $68-98 \%$ of crop air-dry weed biomass and $84-98 \%$ of the total weed number. Perennial weeds comprised $2-32 \%$ of total weed air-dry biomass and $2-16 \%$ of the total weed number in the crop. Our results are similar to previous research indicating in Lithuania prevailing weeds as short-lived annual dicotyledons that comprise $70-90 \%$ of total spread weeds [4, 29]. Consequently, in the experimental spring barley agrophytocenosis, annual weeds prevailed that are commonly spread by seeds while perennials commonly propagate by vegetative parts and spreading by seeds is less important except for infesting new soils. However, Zwerger [30] pays high attention to the perennial weed spreading by seeds analyzing potential danger of Cirsium arvense spreading. From annual weeds in the crop prevailed Chenopodium album, Stellaria media and Sonchus asper while from perennial ones Sonchus arvensis. During all three years of experiment, 40 weed species, 32 annual and 8 perennial, were found. Twenty-six weed species were established in spring barley agrophytocenosis during the first year, 19 during the second and 21 during the third year of the experiment (Table 1). 


\begin{tabular}{|c|c|c|c|c|c|c|}
\hline \multirow{3}{*}{ Weeds } & \multicolumn{6}{|c|}{ Weed density and air-dry biomass } \\
\hline & \multicolumn{2}{|c|}{1997} & \multicolumn{2}{|c|}{1998} & \multicolumn{2}{|c|}{1999} \\
\hline & weeds $\mathrm{m}^{-2}$ & $\mathrm{~g} \mathrm{~m}^{-2}$ & weeds $\mathrm{m}^{-2}$ & $\mathrm{~g} \mathrm{~m}^{-2}$ & weeds $\mathrm{m}^{-2}$ & $\mathrm{~g} \mathrm{~m}^{-2}$ \\
\hline Amaranthus spp. L. & 0 & 0.0 & 0 & 0.0 & 10.83 & 0.14 \\
\hline Anthemis arvensis L. & 0 & 0.0 & 0 & 0.0 & 0 & 0.0 \\
\hline Anthemis tinctoria $\mathrm{L}$. & 0 & 0.0 & 0 & 0.0 & 0 & 0.0 \\
\hline Apera spica-venti (L.) P.Beauv. & 0 & 0.0 & 0 & 0.0 & 0 & 0.0 \\
\hline Atriplex patula L. & 0 & 0.0 & 0 & 0.0 & 0 & 0.0 \\
\hline Avena fatua L. & 0 & 0.0 & 0 & 0.0 & 0 & 0.0 \\
\hline Capsella bursa-pastoris (L.) Medik. & 17.1 & 1.37 & 2.50 & 0.44 & 13.33 & 1.40 \\
\hline Chaenorrhinum minus (L.) Lange & 0.4 & 0.01 & 1.25 & 0.04 & 2.50 & 1.57 \\
\hline Chenopodium album L. & 29.5 & 131.3 & 70.0 & 53.96 & 66.25 & 5.67 \\
\hline Cirsium arvense (L.) Scop. & 2.9 & 5.58 & 2.08 & 3.43 & 0.83 & 0.25 \\
\hline Crepis tectorum L. & 3.3 & 0.88 & 0 & 0.0 & 0 & 0.0 \\
\hline Elytrigia repens (L.) Nevski & 0 & 0.0 & 0 & 0.0 & 2.5 & 2.3 \\
\hline Erysimum cheiranthoides L. & 62.1 & 6.39 & 1.67 & 0.19 & 1.25 & 0.08 \\
\hline Euphorbia helioscopia L. & 3.8 & 0.18 & 0.83 & 0.20 & 0.83 & 0.05 \\
\hline Fallopia convolvulus (L.) A. Löve & 2.1 & 0.14 & 5.42 & 1.45 & 0 & 0.0 \\
\hline Galeopsis tetrahit L. & 0 & 0.0 & 1.67 & 0.29 & 0 & 0.0 \\
\hline Galinsoga parviflora Cav. & 0 & 0.0 & 0.83 & 0.17 & 0 & 0.0 \\
\hline Galium aparine L. & 2.5 & 0.30 & 2.08 & 1.08 & 0 & 0.0 \\
\hline Lamium purpureum L. & 1.2 & 0.05 & 0 & 0.0 & 0.83 & 0.18 \\
\hline Medicago lupulina L. & 1.2 & 0.18 & 0 & 0.0 & 0 & 0.0 \\
\hline Mentha arvensis L. & 0 & 0.0 & 0 & 0.0 & 1.67 & 0.28 \\
\hline Myosotis arvensis (L.) Hill. & 1.7 & 0.13 & 0 & 0.0 & 0 & 0.0 \\
\hline Plantago major L. & 2.5 & 0.13 & 0.42 & 0.81 & 2.92 & 0.06 \\
\hline Poa annua L. & 7.5 & 0.50 & 0 & 0.0 & 5.0 & 0.10 \\
\hline Polygonum aviculare L. & 0.4 & 0.07 & 0 & 0.0 & 0 & 0.0 \\
\hline Polygonum laphatifolium L. & 8.3 & 0.91 & 3.75 & 0.56 & 0.42 & 0.01 \\
\hline Raphanus raphanistrum L. & 0.4 & 0.17 & 0 & 0.0 & 0 & 0.0 \\
\hline Rumex crispus L. & 0 & 0.0 & 0 & 0.0 & 0 & 0.0 \\
\hline Sinapis arvensis L. & 147.9 & 69.23 & 1.67 & 1.05 & 0 & 0.0 \\
\hline Sonchus asper (L.) Hill. & 16.4 & 8.98 & 3.33 & 5.21 & 0.87 & 0.44 \\
\hline Sonchus arvensis L. & 0.3 & 0.17 & 15.84 & 24.77 & 6.21 & 3.14 \\
\hline
\end{tabular}




\begin{tabular}{|c|c|c|c|c|c|c|}
\hline \multirow{3}{*}{ Weeds } & \multicolumn{6}{|c|}{ Weed density and air-dry biomass } \\
\hline & \multicolumn{2}{|c|}{1997} & \multicolumn{2}{|c|}{1998} & \multicolumn{2}{|c|}{1999} \\
\hline & weeds $\mathrm{m}^{-2}$ & $\mathrm{~g} \mathrm{~m}^{-2}$ & weeds $\mathrm{m}^{-2}$ & $g^{-2}$ & weeds $\mathrm{m}^{-2}$ & $\mathrm{~g} \mathrm{~m}^{-2}$ \\
\hline Spergula arvensis L. & 0 & 0.0 & 0.42 & 0.25 & 0 & 0.0 \\
\hline Stellaria graminea L. & 0 & 0.0 & 0 & 0.0 & 0.42 & 0.01 \\
\hline Stellaria media (L.) Vill. & 37.9 & 17.13 & 7.08 & 3.79 & 9.17 & 2.73 \\
\hline Thlaspi arvense L. & 4.6 & 0.49 & 0 & 0.0 & 0.42 & 0.08 \\
\hline Tripleurospermum inodorum (L.) Sch. Bip. & 34.2 & 10.92 & 0 & 0.0 & 2.92 & 0.22 \\
\hline Trifolium pratense $\mathrm{L}$. & 1.2 & 0.02 & 0 & 0.0 & 0 & 0.0 \\
\hline Tussilago farfara L. & 0 & 0.0 & 1.25 & 0.12 & 0 & 0.0 \\
\hline Veronica arvensis L. & 2.5 & 0.08 & 0 & 0.0 & 4.17 & 0.09 \\
\hline Viola arvensis Murray & 3.3 & 0.18 & 0.42 & 0.04 & 1.67 & 0.05 \\
\hline Annual & 388.3 & 249.54 & 102.92 & 68.72 & 120.46 & 12.81 \\
\hline Perennial & 7.0 & 5.90 & 19.59 & 29.13 & 14.55 & 6.13 \\
\hline All weeds & 395.3 & 255.4 & 122.5 & 97.8 & 135.0 & 18.9 \\
\hline
\end{tabular}

Table 1. Composition, density and air-dry biomass of weed species in agrophytocenosis of spring barley on separate fields $[1,31]$

Weed density linearly depended on weed air-dry biomass. With increase of air-dry weed biomass by 1 gram per square meter weed density enlarges by 1.21 weed plants. There was established opposite dependence of weed air-dry biomass on weed density. It showed change of weed air-dry biomass by $0.7 \mathrm{~g} \mathrm{~m}^{-2}$ with change of weed density by 1 plant (Figure 3 ).
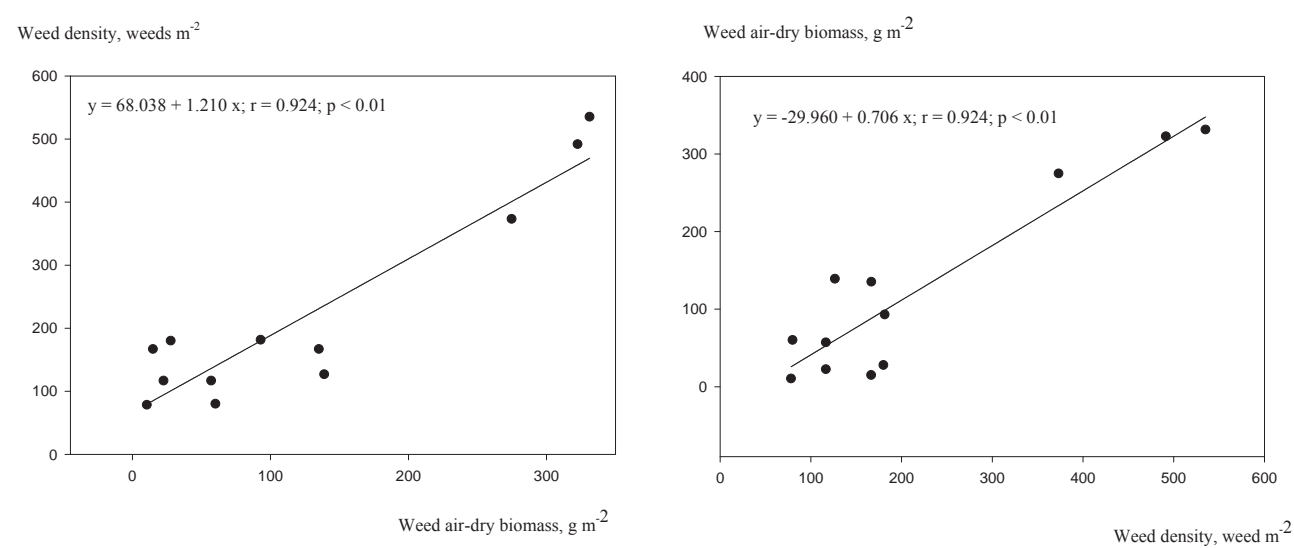

Figure 3. Relationship between weed density and weed air-dry biomass [1, 31] 


\section{Weed seed rain}

\subsection{Weed seed rain initiation}

Dispersed weed seeds in spring barley agrophytocenosis during three years of the experiment belonged to 29 weed species from 12 families (Table 2). Weed seed rain in spring barley begins when spring barley is at stem elongation stage and increases to the hard stage of maturity. Ephemeral weeds of short vegetation Stellaria media and Poa annua as well the early summer weed Chenopodium album matured and began to disperse their seeds at the stem elongation of spring barley.

Winter annual weeds such as Capsella bursa-pastoris ripened and dispersed seeds at heading growth stage of spring barley, usually in the third ten-day period of June. Spring barley changing into early milk stage of maturity, Lamium purpureum, Apera spica-venti, Atriplex patula, Veronica arvensis, Sonchus asper and Myosotis arvensis ripened and began to pour seeds. At milk (medium milk) stage of spring barley maturity, Thlaspi arvensis, Raphanus raphanistrum, Spergula arvensis, Galium aparine, Fallopia convolvulus and Polygonum laphatifolium ripened and began to pour seeds. Spring barley changing from milk into dough stage of maturity, Sinapis arvensis, Sonchus arvensis, Erysimum cheiranthoides and Cirsium arvense ripened and began to disperse seeds. At dough stage of spring barley maturity, Avena fatua, Crepis tectorum, Anthemis arvensis and Anthemis tinctoria ripened their seeds. At dough stage of spring barley maturity, all weed species of agrophytocenosis which seeds were ripened except in 1998 when Crepis tectorum seeds matured and began to disperse only at hard stage of spring barley maturity [2].

The experimental data showed that Crepis tectorum, Cirsium arvense and Sonchus arvensis ripened and began to disperse seeds the latest. However, during separate experimental years the beginning of seed ripeness and start of seed rain for some weed species lasted more than presented the first growth stages of spring barley through the uneven meteorological conditions during separate years of field experiment. As example can serve, Chenopodium album seeds began to disperse at stem elongation stage of spring barley in 1997, at heading growth stage in 1999 and at milk (medium milk) maturity in 1998. Mainly it depended on the year climatic conditions (see subchapter 4.3) and on general crop stand weediness (Figure 4).

\subsection{Weed seed rain dynamics}

Weed seed rain is more intensive in weedier cereal crop, considering weed density and especially weed air-dry weight. It was confirmed by the correlation-regression analysis. Weed seed rain linearly and positively depended on weed dry weight $r=0.842^{* *}$ and on weed density $\mathrm{r}=0.686^{*}$. Weed air-dry biomass increase of $1 \mathrm{~g} \mathrm{~m}^{-2}$ induced increase of weed seed rain by 11.7 seeds $\mathrm{m}^{-2}$ while increase in weed density by one plant enhanced weed seed rain by 7.3 seeds $\mathrm{m}^{-2}$. Hence, total weed seed rain was more dependent on the weed air-dry biomass than on weed density (Figure 4). 


\begin{tabular}{|c|c|c|c|c|}
\hline \multirow[t]{2}{*}{ Family } & \multirow[t]{2}{*}{ Species } & \multicolumn{3}{|c|}{ The beginning of seed rain } \\
\hline & & 97 & 98 & 99 \\
\hline Boraginaceae Juss. & Myosotis arvensis (L.) Hill. & M. & N. & M.e. \\
\hline \multirow{2}{*}{ Chenopodiaceae Less. } & Atriplex patula L. & M. & M. & M.e. \\
\hline & Chenopodium album L. & S.e. & M.e. & He. \\
\hline \multirow{5}{*}{ Cruciferae B. Juss. } & Capsella bursa-pastoris (L.) Medik. & M. & M. & He. \\
\hline & Erysimum cheiranthoides L. & M.I.-D.e. & D. & N. \\
\hline & Raphanus raphanistrum L. & M. & M.I.-D.e. & N. \\
\hline & Sinapis arvensis L. & M.I.-D.e. & M.I.-D.e. & M.I.-D.e. \\
\hline & Thlaspi arvense L. & M. & N. & M. \\
\hline \multirow{7}{*}{ Compositae Giseke } & Anthemis arvensis $\mathrm{L}$. & D. & N. & N. \\
\hline & Anthemis tinctoria L. & D. & N. & N. \\
\hline & Cirsium arvense (L.) Scop. & D. & M.I.-D.e. & D. \\
\hline & Crepis tectorum L. & D. & $\mathrm{H}$. & N. \\
\hline & Sonchus asper (L.) Hill. & M.I.-D.e. & M. & M.e. \\
\hline & Sonchus arvensis L. & D. & M.I.-D.e. & D. \\
\hline & Tripleurospermum inodorum (L.) Sch. Bip. & D. & N. & D. \\
\hline \multirow{2}{*}{ Caryophyllaceae Juss. } & Stellaria media (L.) Hill. & S.e. & M.e. & He. \\
\hline & Spergula arvensis $\mathrm{L}$. & N. & M.I.-D.e. & N. \\
\hline Euphorbiaceae J. St. Hill. & Euphorbia helioscopia L. & N. & N. & M. \\
\hline Labiatae Juss. & Lamium purpureum L. & M.e. & M. & N. \\
\hline \multirow{3}{*}{ Poaceae Bernhart } & Apera spica-venti (L.) P. Beauv. & N. & M.e. & N. \\
\hline & Avena fatua L. & N. & M. & N. \\
\hline & Poa annua L. & S.e. & N. & N. \\
\hline \multirow{4}{*}{ Polygonaceae Lindl. } & Fallopia convolvulus L. & D. & M. & M. \\
\hline & Polygonum lapathifolium L. & M. & M.I.-D.e. & M. \\
\hline & Polygonum aviculare L. & M. & N. & $\mathrm{N}$. \\
\hline & Rumex crispus L. & D. & N. & N. \\
\hline Rubiaceae Juss. & Galium aparine L. & M.I.-D.e. & M.I.-D.e. & N. \\
\hline Scrophulariaceae Juss. & Veronica arvensis L. & M. & M.e. & M. \\
\hline Violaceae Juss. & Viola arvensis Murr. & N. & M.I.-D.e. & N. \\
\hline
\end{tabular}

Note. Spring barley growth stages of maturity: S.e. - stem elongation, He. - heading, M.e. - early milk, M. - milk, M.I.-D.e. - late milk-early dough, D. - dough, H. - hard, N. - weed seed rain was not established.

Table 2. Weed seed rain initiation in spring barley agrophytocenosis [1, 2] 

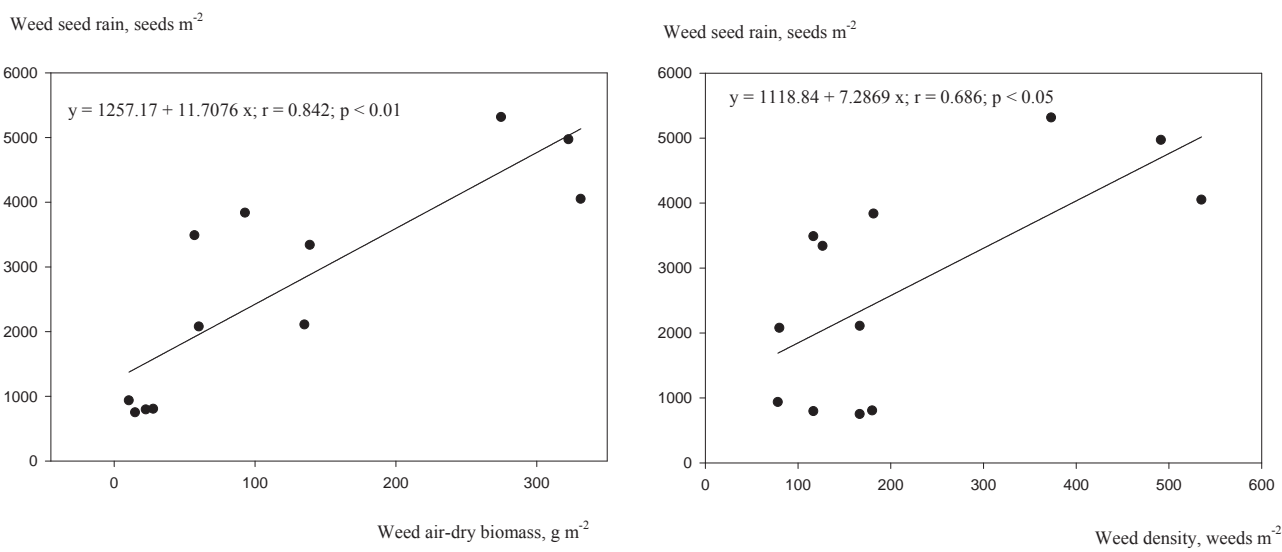

Figure 4. Weed seed rain dependence on weed air-dry biomass and density [1, 31]

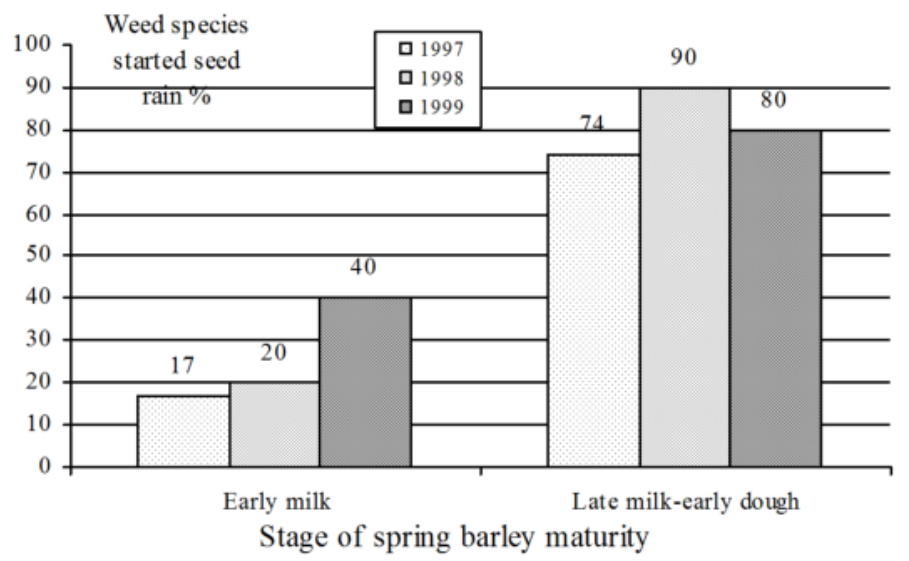

Figure 5. Weed species [\%] started seed rain depending on spring barley crop maturity

It was established that seed rain depended directly on plant density of Stellaria media $\mathrm{r}=0.711^{*}$, Sonchus asper $\mathrm{r}=0.918^{* * *}$ and Capsella bursa-pastoris $\mathrm{r}=0.474$. Accumulated Stellaria media, Sonchus asper and Capsella bursa-pastoris air-dry biomass in the crop had adequate influence on their seed rain, respectively $r=0.833^{* *}, r=0.786^{*}$ and $r=0.766^{*}$ [32]. When spring barley was ripening, weed seed rain was more intensive (Figure 5 and 6 ). It is in conformity with data of other researchers indicating that, until cereal harvesting, some weed species are able to pour out all their ripened seeds [33].

Weed seed rain during separate years of the experiment varied in accordance with the spring barley crop weediness. However, seeds matured and dispersed 29 (Figure 7) of 40 weed species (Table 1) grown in spring barley agrophytocenosis. Presumptively it was influenced by the low density of some weed species and limiting solar light to others by successful smothering 


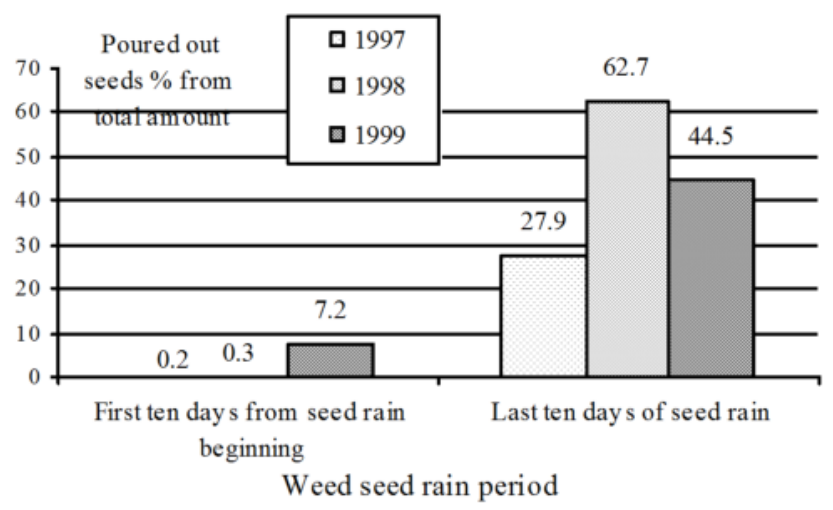

Figure 6. Weed seed rain intensity during vegetation in agrophytocenosis of spring barley

by spring barley. The most important weed species in weed seed rain dynamics biologically belonged to annual weeds. Dispersed seeds of Stellaria media in spring barley agrophytocenosis composed $19-29 \%$ from total seed rain during experimental years. Seed rain of Chenopodium album covered from $6 \%$ to $63 \%$ of total weed seed rain while Capsella bursa-pastoris $6 \%-10 \%$. Seed rain of Sonchus asper and Sinapis arvensis was essential only during the first year of experiment with $26 \%$ and $11 \%$ of seeds from total number of dispersed ones, accordingly. From perennial weeds only Sonchus arvensis showed significant seed rain covering $4.8 \%$ of total dispersed weed seed number during the second year of experiment. Seed rain of all other weeds in spring barley agrophytocenosis jointly consisted from $11 \%$ to $19 \%$ from total number of dispersed weed seeds (Figure 7).

The data of the field trial proved that weeds ripened regularly. Analyzing seed rain of all weed species of spring barley agrophytocenosis were established 4543 seeds $\mathrm{m}^{-2}$ in 1997, 2753 seeds $\mathrm{m}^{-2}$ in 1998 and 821 seeds $\mathrm{m}^{-2}$ in 1999 (Table 3).

Different number of dispersed weed seeds depended on crop and meteorological conditions. Initially, weed seed rain every year of the experiment was slow with low numbers of weed species and low numbers of dispersed seeds. At medium milk stage of spring barley maturity, dispersed seed covered just $6 \%-23 \%$ of total seeds. At late milk-early dough stage of spring barley maturity, it already covered $27 \%-42 \%$ of total dispersed weed seed number. Usually, weed seeds which were left in the crop could be taken from the field together with harvest (biomass of spring barley for silage) and would not infest the soil. Harvesting spring barley for biomass or silage at medium milk stage of maturity, $77 \%-94 \%$ of weed seeds would be removed from the field while harvesting at late milk-early dough stage of maturity, $58 \%-73 \%$ of weed seeds could be removed from the field. When harvesting cereal at hard stage of maturity, most of the weed seeds already are dispersed on the soil and naturally increase weed infestation in the following crop of the crop rotation. 


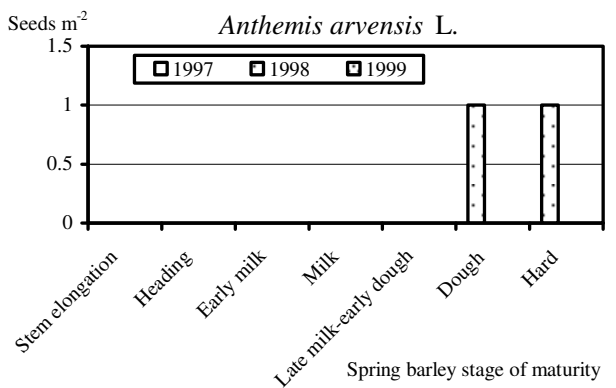

Seeds $\mathrm{m}^{-2} \quad$ Apera spica-venti (L.) P. Beauv.
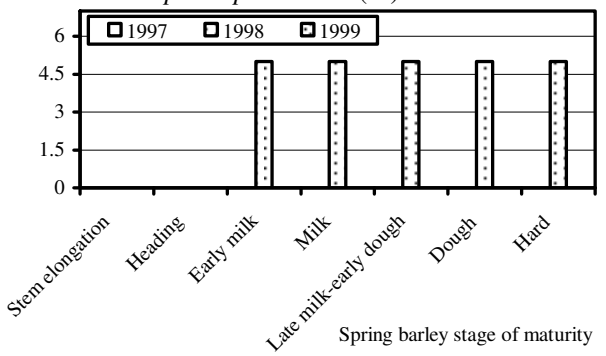

Seeds $\mathrm{m}^{-2}$

Avena fatua L.

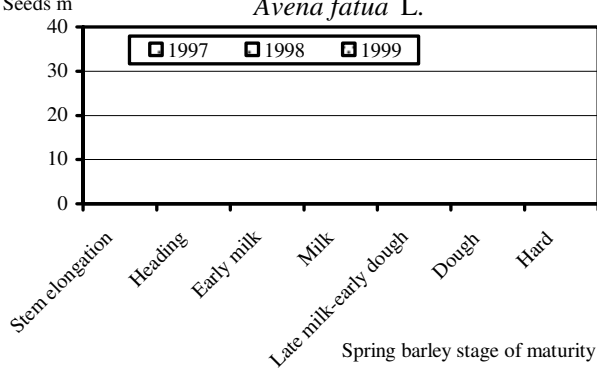

Seeds $\mathrm{m}^{-2} \quad$ Chenopodium album $\mathrm{L}$.

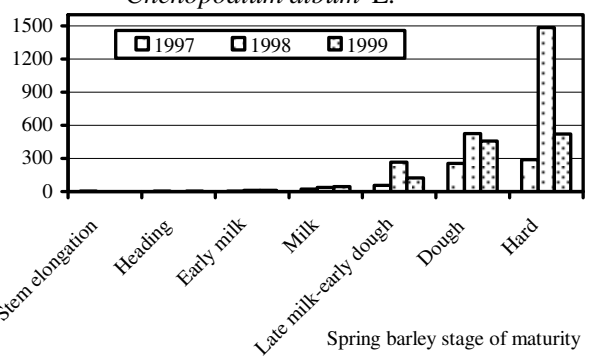

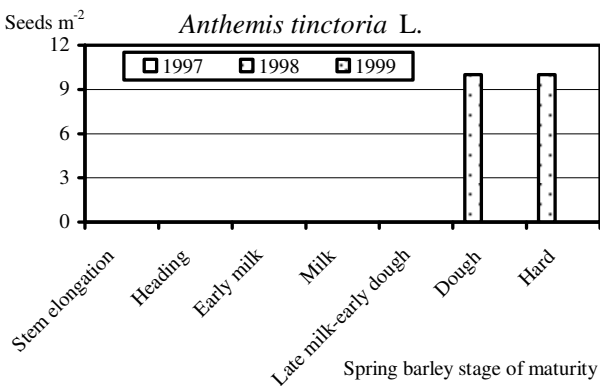

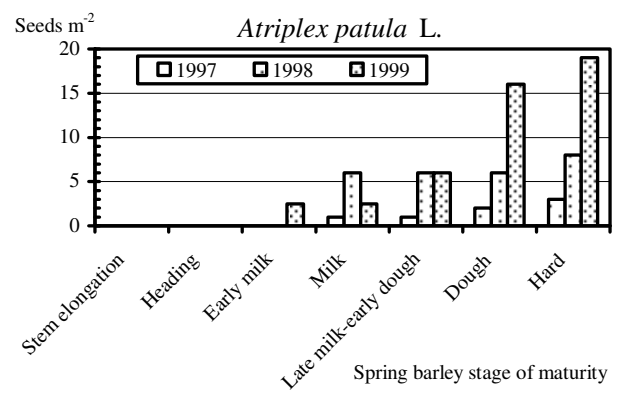

Seeds $\mathrm{m}^{-2} \quad$ Capsella bursa-pastoris (L.) Medik.

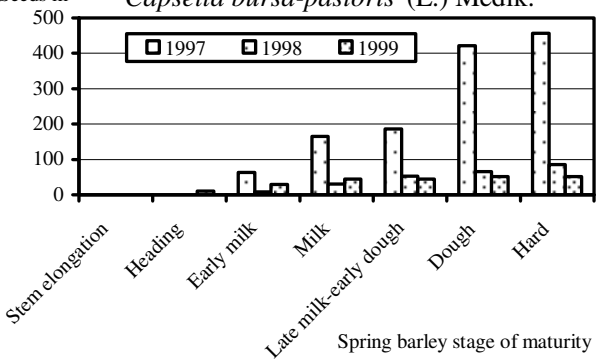

Seeds $\mathrm{m}^{-2} \quad$ Cirsium arvense (L.) Scop.

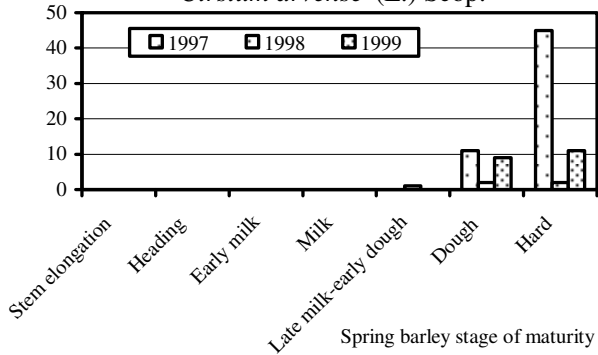



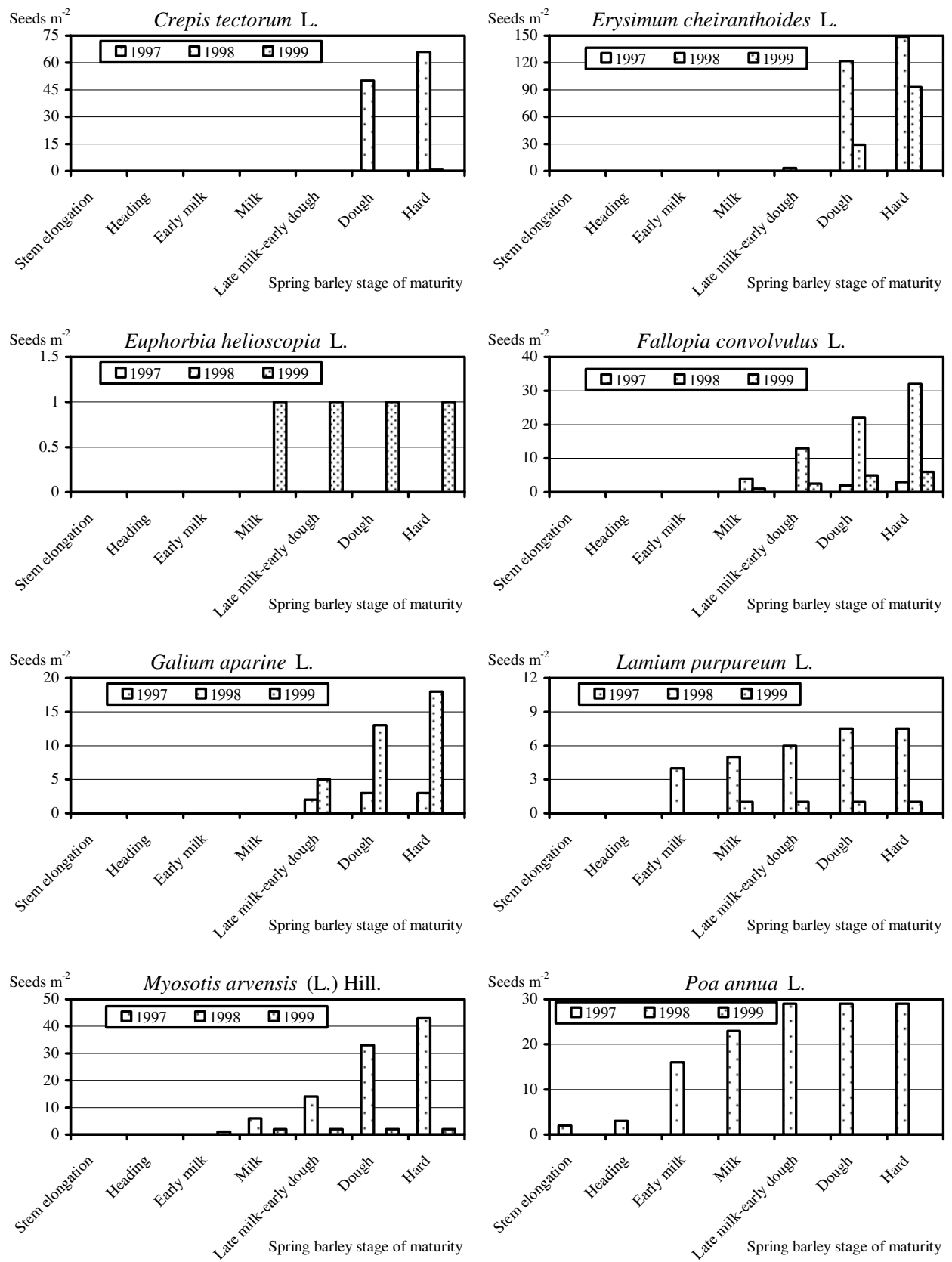

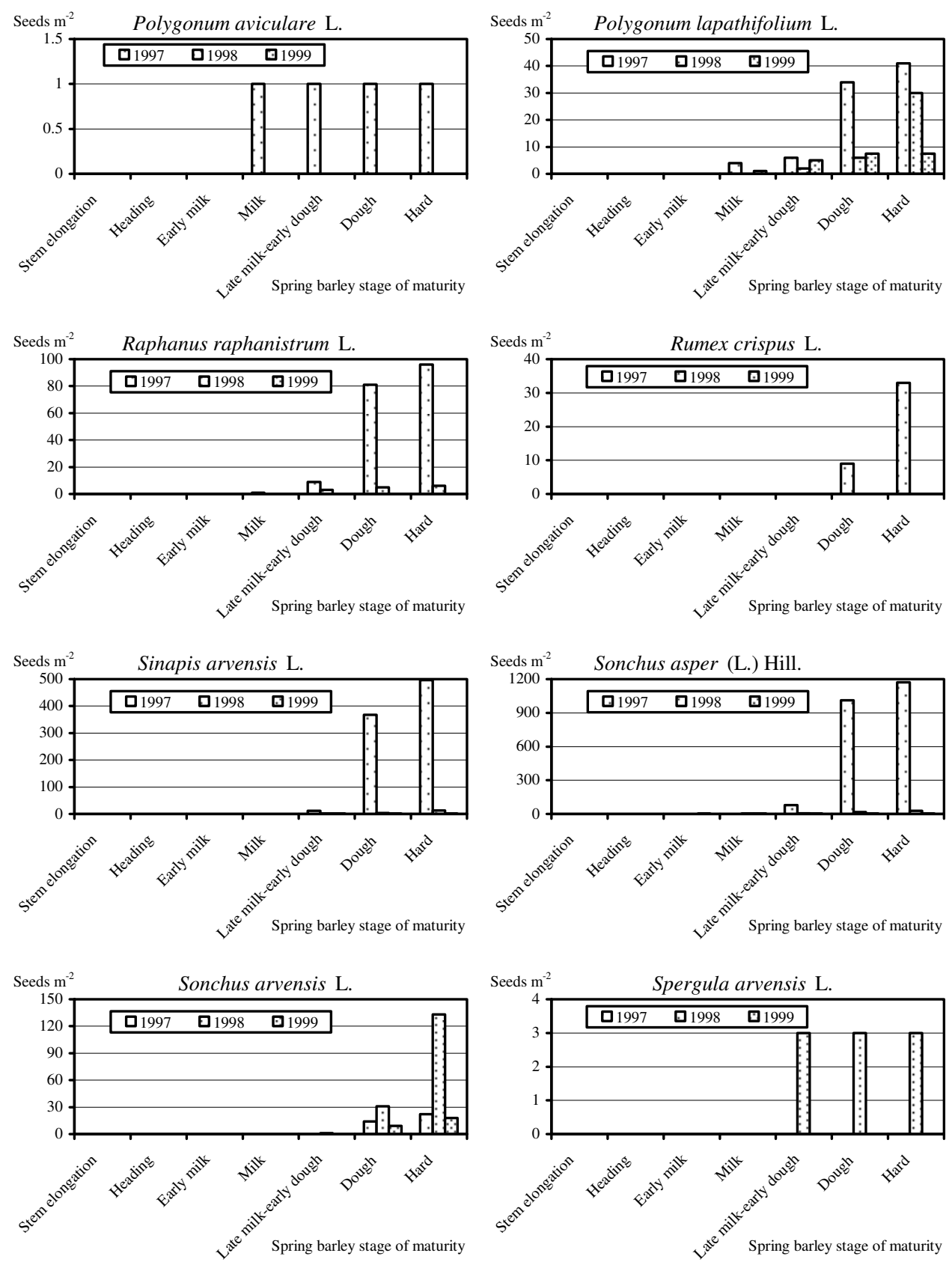

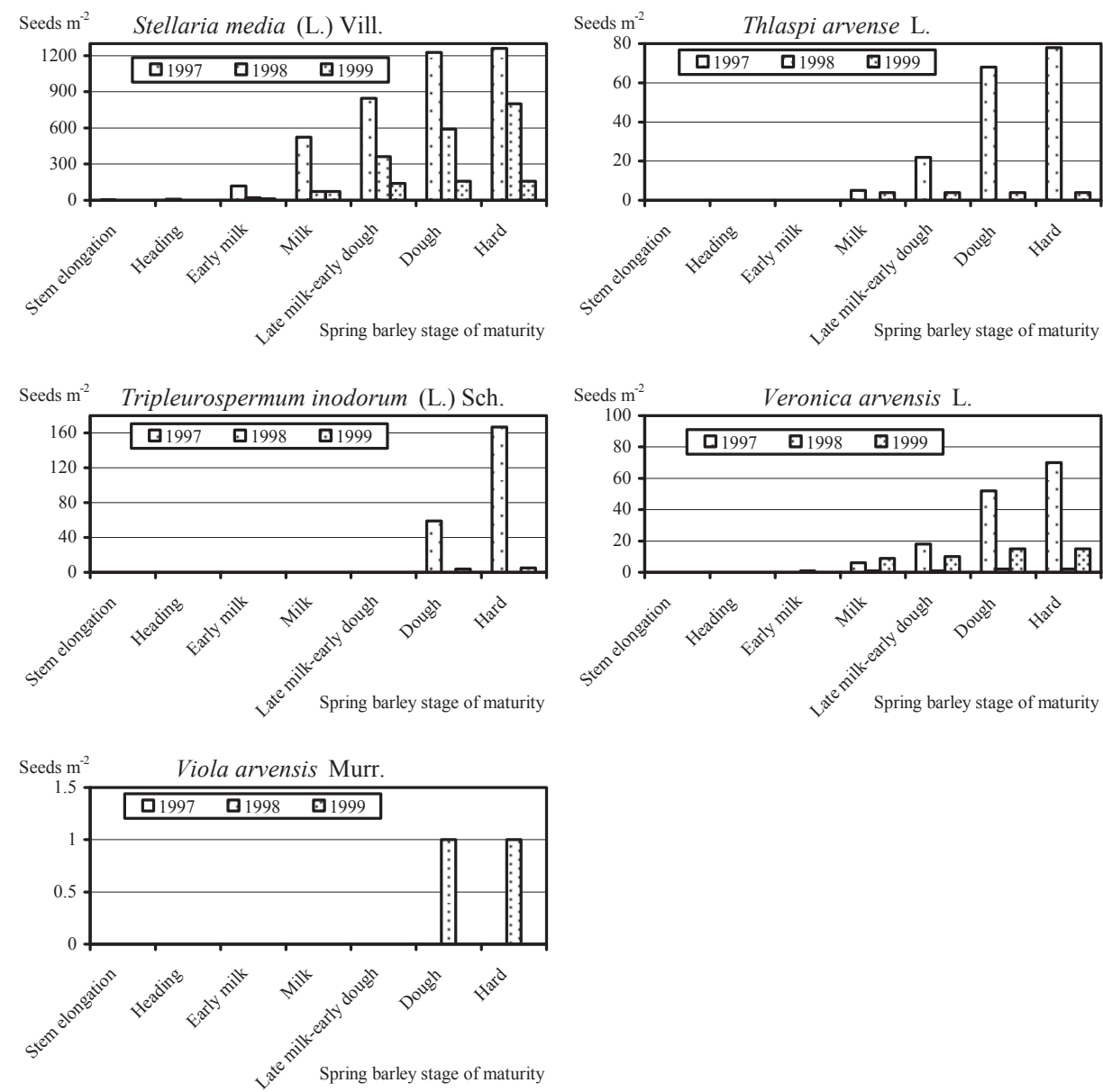

Figure 7. Weed species seed rain dynamics in spring barley agrophytocenosis [1, 2]

Moreover, most weed seeds which, together with crop biomass, get in silage [35-38], in manure $[36,37,39]$, in sewage [40] in compost [41], or going through alimentary canal of cattle [35, 42], lost their germinating power and would not infest the crop in the future.

\subsection{Weed seed rain and meteorological conditions}

Weed seed rain increases during the time of cereal ripening (Figure 4, 6, Table 3) but it decreases in separate vegetation periods depending on change of meteorological conditions. Growth and development of all plants are influenced by environmental factors from which meteorological ones are highly important [43]. 


\begin{tabular}{ccccccc}
\hline & \multicolumn{5}{c}{ Weed seed rain } \\
\cline { 2 - 7 } Stages of spring barley maturity & \multicolumn{2}{c}{1997} & \multicolumn{2}{c}{1998} & 1999 \\
\cline { 2 - 7 } & seed $\mathrm{m}^{-2}$ & $\%$ & seed $\mathrm{m}^{-2}$ & $\%$ & seed $\mathrm{m}^{-2}$ & $\%$ \\
\hline Stem elongation & $8^{* *}$ & 0.17 & $0^{* *}$ & 0.0 & $0^{* *}$ & 0.0 \\
\hline Heading & $16^{* *}$ & 0.35 & $0^{* *}$ & 0.0 & $12^{* *}$ & 1.5 \\
\hline Early milk & $207^{* *}$ & 4.6 & $47^{* *}$ & 1.7 & $60^{* *}$ & 7.3 \\
\hline Milk (medium milk) & $764^{* *}$ & 16.8 & $161^{* *}$ & 5.8 & $189^{* *}$ & 23.0 \\
\hline Late milk-early dough & $1289^{* *}$ & 28.4 & $731^{* *}$ & 26.6 & $343^{* *}$ & 41.8 \\
\hline Dough & 3871 & 85.2 & $1331^{* *}$ & 48.3 & $744^{*}$ & 90.6 \\
\hline Hard & 4543 & 100 & 2753 & 100 & 821 & 100 \\
\hline
\end{tabular}

Table 3. Total weed seed rain in the crop of spring barley $[1,9,34] ;{ }^{*} p<0.05 ;{ }^{* *} p<0.01$

Meteorological conditions such as temperature, rainfall, and sunlight at sprouting and germination stage influenced vegetation and can determine plant density in the crop. For example, germination of Solanum elaeagnifolium [44] and Matricaria perforata [45] depends on temperature, germination of Rumex obtusifolius depends on temperature and light [46], germination of Ranunculus repens depends on soil humidity and temperature [47]. Growth and biomass accumulation of Chenopodium album [48], Bromus tectotum and Taeniatherum asperum [49] also depends on meteorological conditions. In our experiments there was determined linear relationship between weed biomass and weed seed rain (Figure 4). Logically, weed seed rain could be influenced by the meteorological factors such as air temperature, rainfall and sunlight duration. According to the sum of active air temperature and precipitation, the vegetation period during the first and the second experimental years was wet and during the third experimental year - not humid enough (Figure 8).

Weed seed rain changed dynamically, increasing and decreasing during vegetation regardless of total seed number dispersed during separate years of experiment (Figure 7). In our experiment, established weed seed rain fluctuations significantly depended on active air temperature $\left(>10^{\circ} \mathrm{C}\right)$, rainfall and sunlight duration (Figures 9-11). Weed seed rain regularly intensified with increase of sum of active air temperature (Figure 9) as well as with increase of sunlight duration (Figure 11). This phenomenon is based on plant physiological processes such as development and water circulation in plant tissues that are significantly dependent on sunlight and environmental temperature. In contrast to the sum of active air temperature and sunlight duration, rainfall inhibited weed seed rain (Figure 10). Jointly, during rainy periods, active air temperatures decreased and shortened sunlight duration which leads to an increase of humidity accumulation in plants. Excess humidity amounts reaching weed seeds managed to slow physiological maturation and as well inhibited seed rain. Statistically reliable non-linear dependencies of total weed seed rain on active air-temperatures $r^{2}=0.528^{* *}, r^{2}=0.538^{* *}, r^{2}=0.119^{*}$, 
rainfall $\mathrm{r}^{2}=0.567^{* *}, \mathrm{r}^{2}=0.608^{* *}, \mathrm{r}^{2}=0.155^{*}$ and sunlight duration $\mathrm{r}^{2}=0.512^{* *}, \mathrm{r}^{2}=0.418^{* *}, \mathrm{r}^{2}=0.136^{*}$ are presented in figures $9-11$.
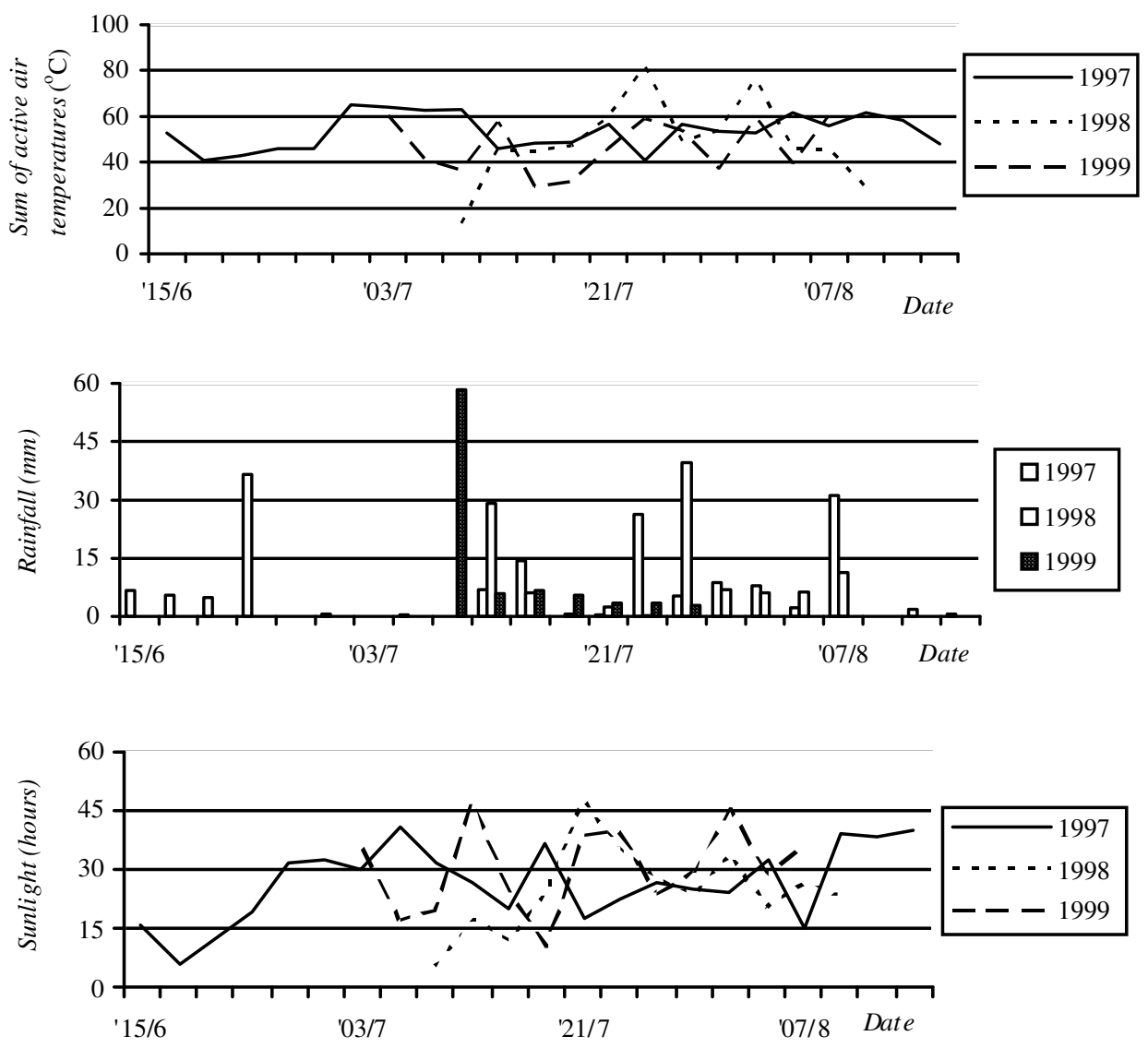

Figure 8. Meteorological conditions: active air temperatures, rainfall and sunlight dynamics during experimental years, Kaunas (Noreikiškès) Meteorological station [43]

\subsection{Weed seeds in grains}

The later the cereal harvest, the fewer amounts of weed seeds get into grain, but the more of them infested the soil [12]. In cereal grain yield of hard maturity (in the sample of $100 \mathrm{~g}$ ), on average, are found less weed seeds by 820 when comparing with grain yield of dough maturity. Such decrease makes up to 21 million (12-39 million) fewer weed seeds in crop yield from 1 ha with a biomass of approximately $38 \mathrm{~kg}(13-53 \mathrm{~kg})$. This regularity motivates the necessity of earlier spring barley harvesting not only because of frequently experienced grain losses but also because of weed seed spreading limitation [50]. 

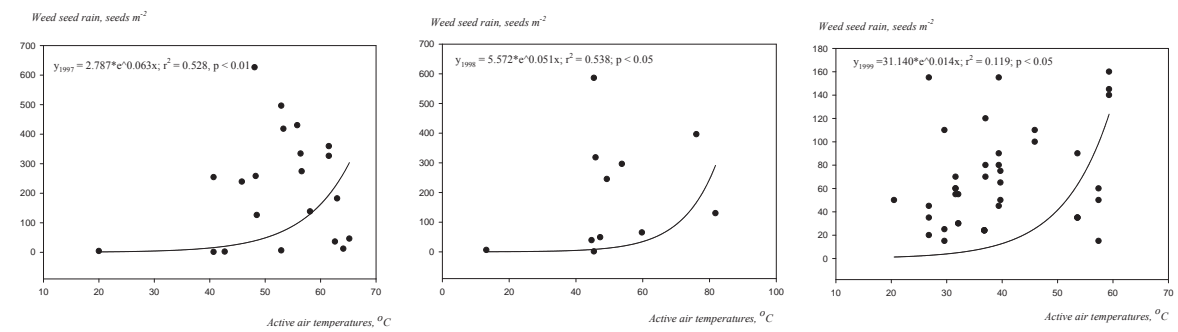

Figure 9. Weed seed rain dependence on active air temperatures [43]
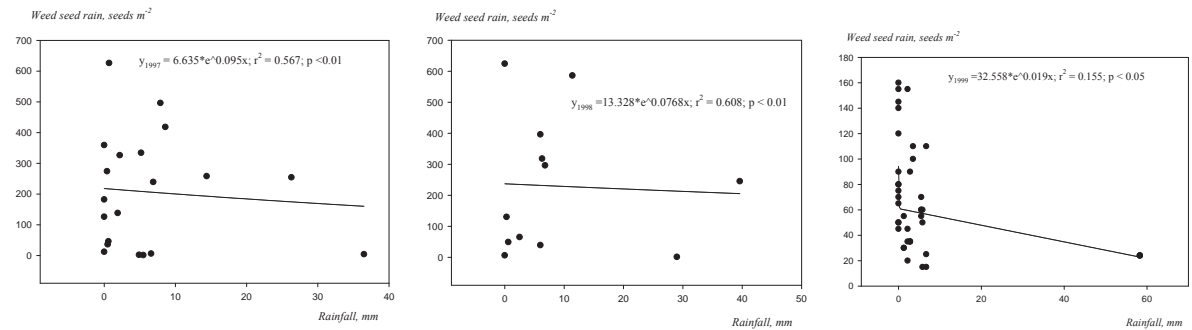

Figure 10. Weed seed rain dependence on rainfall [43]
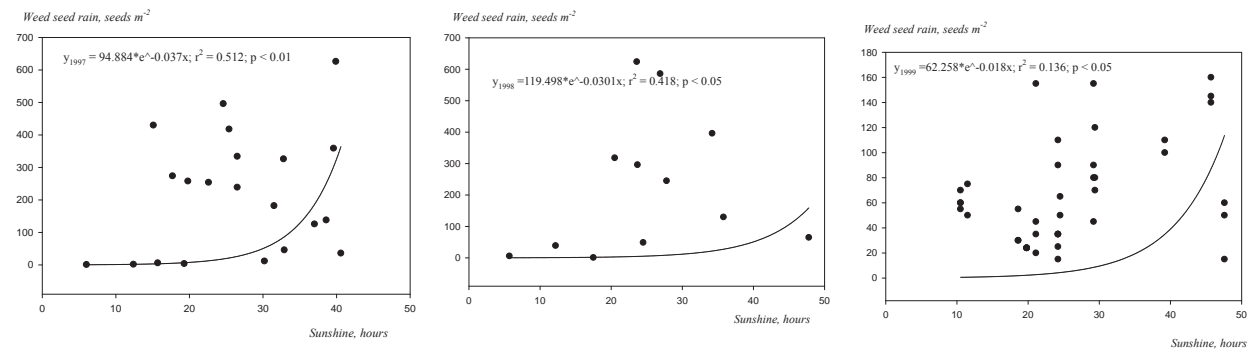

Figure 11. Weed seed rain dependence on sunshine duration [43]

\subsection{Spring barley crop productivity}

Spring barley dry matter yield increased significantly while cereal matured from stem elongation to late milk-early dough growth stages. In the further growth stages of spring barley - dough and hard - total above-ground dry matter yield decreased significantly (Figure 12). The yield of dry matter begins to decrease at anthesis complete growth stage of spring barley [51]. The optimal period for gathering cereal is considered 4 weeks after heading [52] or 2-3 weeks before hard growth stage, when dry matter yield reaches maximum and begins to decrease [53]. The maximum increase of dry matter in cereal is characteristic from heading till 
milk stage but the biggest yield accumulates in milk-dough and dough stages of maturity [54], thereafter it decreased slightly for the two-row cultivars [55]. Dynamics of dry matter in cereal can be influenced by meteorological conditions, soil, fertilization and other factors [56]. However, dynamics of dry matter accumulation in cereals depends on decrease of assimilation surface when leaves decline and on allocation and transformation of assimilation products [51, $53,57]$. The general decrease of dry matter yield is influenced by decrease of vegetative biomass [58]. Growth stages of spring barley and other cereals can be theoretically divided into three groups according accumulation dynamics of harvest: increase, reach of maximum, and decrease. The logical solution is to limit yield losses, i.e. to refuse the third group. By cutting cereal at milk-dough stages of maturity, it would be possible to achieve that. Of course, then it would be necessary to refuse conventional harvesting of cereal for grain applying an alternative use of all above-ground biomass for forage at such stage of maturity when maximum yield of dry matter and metabolizable energy is reached [1, 59].

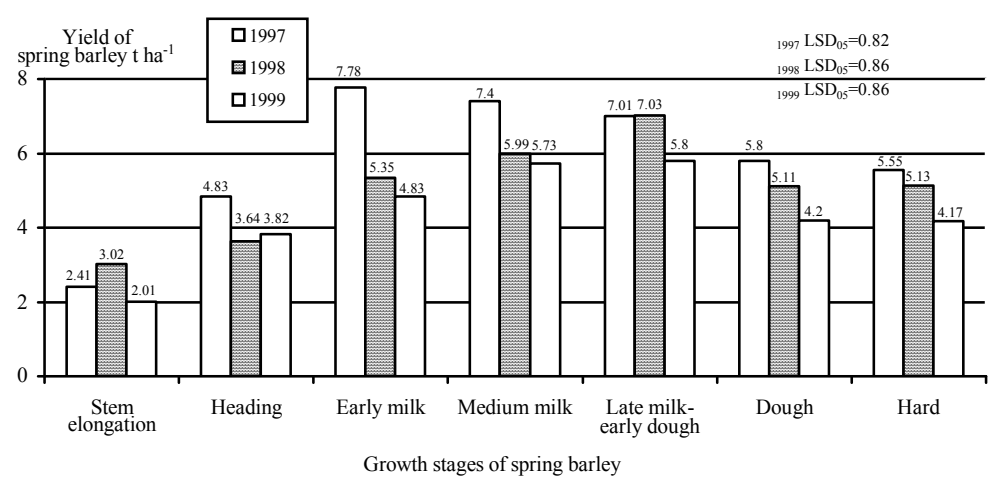

Figure 12. Spring barley dry matter yield at seven stages of growth and maturity $[1,59,60]$

The concentration of crude protein, crude fibre, crude fat and crude ash variation of each year of the experiment preserved analogical tendency (Table 4). The concentration of crude protein and crude ash was the greatest at stem elongation growth stage and as the spring barley matured the concentration of crude protein and crude ash decreased. However, in the grain of dough and hard growth stages, concentration of these components increased but in the straw it decreased. Therefore, total yield of crude protein and crude ash decreased significantly at dough and hard growth stages compared with milk and late milk-early dough stages of spring barley maturity. The concentration of crude fibre and crude fat tended to increase or decrease as the spring barley matured. However, the yield of crude fibre and crude fat at dough and hard growth stages decreased significantly (Table 4).

Likewise, as in our experiment, the greatest concentration of nutrition at stem elongation growth stage of spring barley and other cereals was determined. The concentration of nutrition essentially decreased to minimum at the end of vegetation [61] and remained constant near 
maturity $[55,62]$. At the end of cereal vegetation, growth of DM is zero and biological yield does not increase but even begins to decrease [63]. Losses of DM in spring barley yield can be decreased additionally using nitrogen fertilizers. However, spring barley loses a part of wholeplant DM yield before reaching hard stage in variables of the trials fertilized and non-fertilized by nitrogen [64]. That is because the index of green plant surface area decreases to zero when respiration occurs in plant ears, which requires energy. So, if photosynthesis does not occur, spring barley matures about 3 weeks before harvesting using non-replenished energetic resources. Moreover, development of DM in plant organs fully influences not only the product (grain) but also the growth of a plant and biological yield [59]. Usually the differences between agricultural plants and their varieties are seen in differences of speed usage of DM of assimilation tissues. In some cases, when general biomass of cereal increases, grain yield does not increase because of the development of some assimilation products in vegetative organs [53]. The metabolizable energy (ME) in spring barley yield for ruminants (cows) is given in Table 5. Metabolizable energy is energy directly intaken and used in an animal's organs. Total forage energetic losses are rejected beforehand, which are experienced in an animal's organs for various reasons (energetic losses with feces, urine and intestine gas and energy necessary for digestion processes) [16, 65].

The ME (MJ kg-1 DM) was similar to the chemical composition dynamics. In contrast to the ME content $\left(\mathrm{MJ} \mathrm{kg}^{-1} \mathrm{DM}\right)$, the amount of ME per hectare increased significantly as the spring barley matured to the late milk-early dough growth stage, and likewise, DM, digestible organic matter in the dry matter, crude protein and crude ash yield decreased significantly at dough and hard growth stages.

\begin{tabular}{|c|c|c|c|c|c|c|c|c|}
\hline \multirow{3}{*}{ Growth stage } & \multicolumn{8}{|c|}{ In dry matter } \\
\hline & \multicolumn{2}{|c|}{ Crude protein } & \multicolumn{2}{|c|}{ Crude fibre } & \multicolumn{2}{|c|}{ Crude fat } & \multicolumn{2}{|c|}{ Crude ash } \\
\hline & $\%$ & t ha $^{-1}$ & $\%$ & t ha-1 & $\%$ & t ha-1 & $\%$ & $\mathrm{t} \mathrm{ha}^{-1}$ \\
\hline \multicolumn{9}{|c|}{1997} \\
\hline Stem elongation & 12.98 & 0.31 & 27.32 & 0.66 & 2.42 & 0.06 & 10.76 & 0.26 \\
\hline Heading & 9.60 & 0.46 & 32.13 & 1.55 & 1.69 & 0.08 & 7.99 & 0.39 \\
\hline Early milk & 6.61 & 0.51 & 31.61 & 2.45 & 2.30 & 0.18 & 9.46 & 0.74 \\
\hline Milk (medium milk) & 7.16 & 0.53 & 28.44 & 2.10 & 2.20 & 0.16 & 7.40 & 0.55 \\
\hline Late milk-early dough & 7.71 & 0.54 & 25.27 & 1.77 & 2.11 & 0.15 & 5.34 & 0.37 \\
\hline Dough & - & $0.32^{\#}$ & - & $1.64^{\#}$ & - & $0.12^{\#}$ & - & $0.25^{\#}$ \\
\hline Grain & 7.91 & 0.186 & 6.42 & 0.15 & 2.37 & 0.06 & 2.63 & 0.06 \\
\hline Straw & 3.94 & 0.136 & 43.31 & 1.49 & 1.81 & 0.06 & 5.86 & 0.19 \\
\hline Hard & - & $0.31^{\#}$ & - & $1.62^{\#}$ & - & $0.10^{\#}$ & - & $0.21^{\#}$ \\
\hline Grain & 8.55 & 0.213 & 6.69 & 0.17 & 2.63 & 0.06 & 2.46 & 0.06 \\
\hline Straw & 3.07 & 0.094 & 47.48 & 1.45 & 1.23 & 0.04 & 4.91 & 0.15 \\
\hline
\end{tabular}




\begin{tabular}{|c|c|c|c|c|c|c|c|c|}
\hline \multirow{3}{*}{ Growth stage } & \multicolumn{8}{|c|}{ In dry matter } \\
\hline & \multicolumn{2}{|c|}{ Crude protein } & \multicolumn{2}{|c|}{ Crude fibre } & \multicolumn{2}{|c|}{ Crude fat } & \multicolumn{2}{|c|}{ Crude ash } \\
\hline & $\%$ & $\mathrm{t} \mathrm{ha}^{-1}$ & $\%$ & t ha-1 & $\%$ & t ha-1 & $\%$ & $\mathrm{t} \mathrm{ha}^{-1}$ \\
\hline $\mathrm{LSD}_{05}$ & & 0.05 & & 0.28 & & 0.02 & & 0.06 \\
\hline \multicolumn{9}{|c|}{1998} \\
\hline Stem elongation & 16.60 & 0.50 & 28.57 & 0.86 & 1.74 & 0.05 & 11.30 & 0.34 \\
\hline Heading & 9.66 & 0.35 & 28.90 & 1.05 & 2.73 & 0.10 & 8.49 & 0.31 \\
\hline Early milk & 8.70 & 0.47 & 26.68 & 1.43 & 2.33 & 0.12 & 6.64 & 0.36 \\
\hline Milk (medium milk) & 8.23 & 0.49 & 25.84 & 1.55 & 2.04 & 0.12 & 6.01 & 0.36 \\
\hline Late milk-early dough & 6.88 & 0.48 & 22.10 & 1.55 & 2.39 & 0.17 & 5.21 & 0.37 \\
\hline Dough & & $0.32^{\#}$ & - & $1.37^{\#}$ & - & $0.09^{\#}$ & - & $0.28^{\#}$ \\
\hline Grain & - & 0.20 & 5.32 & 0.116 & 2.65 & 0.058 & 2.89 & 0.06 \\
\hline Straw & 9.20 & 0.12 & 42.85 & 1.251 & 1.25 & 0.036 & 7.54 & 0.22 \\
\hline Hard & 4.04 & $0.39^{\#}$ & - & $1.17^{\#}$ & - & $0.10^{\#}$ & - & $0.18^{\#}$ \\
\hline Grain & - & 0.30 & 5.08 & 0.146 & 2.75 & 0.08 & 2.47 & 0.07 \\
\hline Straw & 10.54 & 0.09 & 45.73 & 1.028 & 1.03 & 0.02 & 5.05 & 0.11 \\
\hline $\mathrm{LSD}_{05}$ & & 0.05 & & 0.24 & & 0.02 & & 0.05 \\
\hline \multicolumn{9}{|c|}{1999} \\
\hline Stem elongation & 14.26 & 0.29 & 23.93 & 0.48 & 2.31 & 0.05 & 10.97 & 0.22 \\
\hline Heading & 9.95 & 0.38 & 28.44 & 1.09 & 2.18 & 0.08 & 6.04 & 0.23 \\
\hline Early milk & 7.60 & 0.37 & 21.70 & 1.05 & 2.16 & 0.10 & 6.75 & 0.33 \\
\hline Milk (medium milk) & 7.98 & 0.46 & 25.05 & 1.43 & 2.64 & 0.15 & 5.87 & 0.34 \\
\hline Late milk-early dough & 7.13 & 0.41 & 23.17 & 1.34 & 2.18 & 0.13 & 4.38 & 0.25 \\
\hline Dough & - & $0.33^{\#}$ & - & $1.00^{\#}$ & - & $0.10^{\#}$ & - & $0.19^{\#}$ \\
\hline Grain & 11.59 & 0.25 & 5.56 & 0.12 & 3.15 & 0.07 & 2.70 & 0.06 \\
\hline Straw & 3.60 & 0.07 & 43.42 & 0.88 & 1.51 & 0.03 & 6.70 & 0.13 \\
\hline Hard & - & $0.34^{\#}$ & - & $0.93^{\#}$ & - & $0.09^{\#}$ & - & $0.19^{\#}$ \\
\hline Grain & 11.93 & 0.27 & 5.79 & 0.13 & 2.89 & 0.07 & 2.89 & 0.06 \\
\hline Straw & 3.78 & 0.07 & 42.48 & 0.79 & 1.45 & 0.03 & 6.84 & 0.13 \\
\hline $\mathrm{LSD}_{05}$ & & 0.07 & & 0.21 & & 0.02 & & 0.06 \\
\hline
\end{tabular}

Table 4. Effect of spring barley growth stage at harvesting on yield chemical composition $[1,59,60]$ 
When spring barley grain matures at hard growth stage compared with dough stage, the yield of DM, crude protein, crude fibre and ME increases. The yield of crude fat and crude ash almost does not differ. However, when the quality of straw becomes worse, the general value of yield remains fewer than at milk-dough stage. Martin and Seibold [66] determined comparable results: ME of $9.56 \mathrm{MJ} \mathrm{kg}^{-1} \mathrm{DM}$ at heading stage of maturity and $\mathrm{ME}$ of grain $12.93 \mathrm{MJ} \mathrm{kg}^{-1} \mathrm{DM}$ and $6.80 \mathrm{MJ} \mathrm{kg}^{-1} \mathrm{DM}$ of straw at hard stage of spring barley maturity.

\begin{tabular}{|c|c|c|c|c|c|c|}
\hline \multirow{2}{*}{ Growth stage } & \multicolumn{3}{|c|}{ ME, MJ kg-1 DM } & \multicolumn{3}{|c|}{ ME, GJ ha-1 } \\
\hline & 1997 & 1998 & 1999 & 1997 & 1998 & 1999 \\
\hline Stem elongation & 10.80 & 9.24 & 9.97 & 26.03 & 27.91 & 20.04 \\
\hline Heading & 10.00 & 9.02 & 8.61 & 48.30 & 32.83 & 32.89 \\
\hline Early milk & 8.38 & 9.54 & 8.01 & 65.20 & 51.04 & 38.69 \\
\hline Milk (medium milk) & 8.49 & 9.45 & 8.56 & 62.74 & 56.61 & 49.05 \\
\hline Late milk-early dough & 8.60 & 9.67 & 8.64 & 60.29 & 67.98 & 50.11 \\
\hline Dough & - & - & - & $51.76^{\#}$ & $42.18^{\#}$ & $38.94^{\#}$ \\
\hline Grain & 11.97 & 11.30 & 11.84 & 28.13 & 24.75 & 25.93 \\
\hline Straw & 6.85 & 5.97 & 6.47 & 23.63 & 17.43 & 13.01 \\
\hline Hard & - & - & - & $50.69^{\#}$ & $46.80^{\#}$ & $36.02^{\#}$ \\
\hline Grain & 12.44 & 12.50 & 11.01 & 30.98 & 36.00 & 25.32 \\
\hline Straw & 6.44 & 4.80 & 5.72 & 19.71 & 10.80 & 10.70 \\
\hline $\mathrm{LSD}_{05}$ & - & - & - & 6.78 & 7.66 & 7.70 \\
\hline
\end{tabular}

ME, metabolizable energy; DM, dry matter; \# - total yield (grain + straw)

Table 5. Energetic value of spring barley over-ground biomass (whole-plant) at seven stages of growth and maturity $[1,59,60]$

Positive, statistically reliable, linear dependence of spring barley crude protein $\left[\mathrm{t} \mathrm{ha}{ }^{-1}\right]$ $\mathrm{r}_{1997}=0.736^{* * *}, \mathrm{r}_{1998}=0.317, \mathrm{r}_{1999}=0.858^{* * *}$, crude fibre [t ha- ${ }^{-1} \mathrm{r}_{1997}=0.964^{* * *}, \mathrm{r}_{1998}=0,937^{* * *}$, $\mathrm{r}_{1999}=0.961^{* * *}$, crude fat $\left[\mathrm{t} \mathrm{ha} \mathrm{H}^{-1}\right] \mathrm{r}_{1997}=0.960^{* * *}, \mathrm{r}_{1998}=0.911^{* * *}, \mathrm{r}_{1999}=0.957^{* * *}$ and crude ash [t ha-1] $\mathrm{r}_{1997}=0.689^{* * *}, \mathrm{r}_{1998}=0.335, \mathrm{r}_{1999}=0.646^{* * *}$ on dry matter yield [ $\left.\mathrm{t} \mathrm{ha} \mathrm{a}^{-1}\right]$ and linear dependence of metabolizable energy $\left[\mathrm{Gj} \mathrm{ha}^{-1}\right]$ on spring barley dry mass $\left[\mathrm{t} \mathrm{ha}{ }^{-1}\right], \mathrm{r}_{1997}=0.992^{* * *}, \mathrm{r}_{1998}=0.985^{* * *}$, $\mathrm{r}_{1999}=0.983^{* * *}$, crude protein [ $\left.\mathrm{t} \mathrm{ha}^{-1}\right] \mathrm{r}_{1997}=0.750^{* * *}, \mathrm{r}_{1998}=0.420^{*}, \mathrm{r}_{1999}=0.844^{* * *}$, crude fibre [ $\mathrm{t} \mathrm{ha}{ }^{-1}$ ] $\mathrm{r}_{1997}=0.967^{* * *}, \mathrm{r}_{1998}=0.900^{* * *}, \mathrm{r}_{1999}=0.948^{* * *}$, crude fat $\left[\mathrm{t} \mathrm{ha}^{-1}\right] \mathrm{r}_{1997}=0.926^{* * *}, \mathrm{r}_{1998}=0.931^{* * *}$, $\mathrm{r}_{1999}=0.953^{* * *}$ and crude ash yields $\left[\mathrm{t} \mathrm{ha}^{-1}\right] \mathrm{r}_{1997}=0.671^{* * *}, \mathrm{r}_{1998}=0.385^{*}, \mathrm{r}_{1999}=0.576^{* *}$ were established [59].

Digestibility in vitro of spring barley organic matter in the dry matter depended on spring barley stage of maturity. The highest digestibility in vitro was established at growth stage of stem elongation $73-78 \%$ (except 1998) and at later growth stages it decreased. Digestibility of 
spring barley whole-plant biomass at stem elongation was less compared with barley grain digestibility at dough and hard stages of maturity (digestibility in vitro to $89 \%$ ). Spring barley metabolizable energy directly depended on barley growth stages and fodder digestible organic matter in the dry matter digestibility in vitro, $r=0.995-0.998$ at $P<0.0001$ [67]. Ensiling spring barley biomass harvested at early milk, milk, late milk-early dough and dough stages of maturity, silage chemical composition directly depended on cereal stage of maturity. Whole plant silage produced from cereals of later stages of maturity, late milk-early dough and dough stages of maturity, has less crude protein and crude ash concentration, lower digestibility in vitro by ruminants and fewer accumulated metabolizable energy $\mathrm{MJ} \mathrm{kg}^{-1}$ of silage dry biomass [68]. Nykänen et al. [69] reported the highest organic matter digestibility in peas (710-800 g $\mathrm{kg}^{-1}$ ), vetches and spring barley had an organic matter digestibility of $670 \mathrm{~g} \mathrm{~kg}^{-1}$, while the other spring cereals had the lowest values (550-610 $\left.\mathrm{g} \mathrm{kg}^{-1}\right)$. The highest organic matter digestibility of spring barley silage was found processing silage from biomass of earlier stage (milk) of spring barley maturity [68].

\subsection{Economic evaluation of technology}

Cereals in Lithuania are some of the most important agricultural crops. In 2011, cereal crop area comprised $51.7 \%$ of all crops [70] while conventionally they cover $60-64 \%$ of crop area [71]. The biggest part of grain (approx. $70 \%$ ) is used for forage [72]. With the increasing intensity of agricultural production, spring barley is becoming one of the most important cereals in Lithuania $[73,74]$. Spring barley covers more than $23 \%$ of total cereal crop area in the country [70]. Edwards et al. [75] proposed that it would be more purposeful to use the whole plant for forage than to feed animals with separate processed grain and straw. Silage significantly decreases cereal processing costs; expensive combining, straw processing, grain transport, grain cleaning and grain drying can be omitted. Moreover, inevitable grain losses, especially due to unfavourable meteorological conditions during the harvest can be avoided. When preparing whole plant silage from late milk-early dough and dough stages of spring barley maturity, higher nutritive value was achieved when evaluating total metabolizable energy received from plot area compared with earlier harvested for biomass or harvested at hard maturity for grains spring barley whole plant above-ground plant part energetic value as fodder for ruminants [68]. Of special interest is, whether in technology can be reduced unnecessary input use [77]. Therefore, the aim of this research was to determine economical efficiency of different spring barley growing and yield harvesting [at late milk-early dough suitable for silage and hay making and hard (grains and straws are obtained) stages of maturity] technologies as well as the economical background.

Due to the maturing process of spring barley, dry matter yield is gradually accumulated by reaching maximum at the late milk-early dough growth stages. The dry matter yield decreased significantly as the spring barley matured from late milk-early dough to hard growth stage (see subchapter 4.5). When harvesting spring barley at two different growth stages, the costs during separate years varied from 604.7 to $869.1 \mathrm{Lt} \mathrm{ha}^{-1}$ and depended on the different yields and proceedings. The costs associated with harvesting spring barley at the late milk-early 


\begin{tabular}{|c|c|c|c|}
\hline \multirow{3}{*}{$\begin{array}{c}\text { Growth stage of harvesting } \\
\text { and operation }\end{array}$} & \multicolumn{3}{|c|}{ Costs $[\text { Lt ha-1 }]^{*}$} \\
\hline & \multicolumn{3}{|c|}{ Year } \\
\hline & 1997 & 1998 & 1999 \\
\hline Late milk-early dough & 659.24 & 674.40 & 604.73 \\
\hline Autumn plough & 76.09 & 76.09 & 76.09 \\
\hline Autumn loosening & 26.03 & 26.03 & 26.03 \\
\hline Spring loosening & 26.03 & 26.03 & 26.03 \\
\hline Spring loosening with harrow & 24.82 & 24.82 & 24.82 \\
\hline Sow & 106.75 & 106.75 & 106.75 \\
\hline Harvest & 16.50 & 16.50 & 16.50 \\
\hline Press to rolls & 199.50 & 214.13 & 176.67 \\
\hline Rolls involve in film & 126.04 & 126.40 & 104.28 \\
\hline Transport & 57.48 & 57.65 & 47.56 \\
\hline Hard & 840.52 & 869.13 & 749.94 \\
\hline Autumn plough & 76.09 & 76.09 & 76.09 \\
\hline Autumn loosening & 26.03 & 26.03 & 26.03 \\
\hline Spring loosening & 26.03 & 26.03 & 26.03 \\
\hline Spring loosening with harrow & 24.82 & 24.82 & 24.82 \\
\hline Sow & 106.75 & 106.75 & 106.75 \\
\hline Harvest & 350.52 & 405.42 & 323.77 \\
\hline Press straw to rolls & 125.74 & 92.45 & 76.84 \\
\hline Grain transport & 25.02 & 28.94 & 23.12 \\
\hline Straw transport & 22.25 & 16.36 & 13.59 \\
\hline Grain clean & 7.47 & 8.64 & 6.90 \\
\hline Grain dry & 49.80 & 57.60 & 46.00 \\
\hline
\end{tabular}

Table 6. Cost structure of spring barley harvested at two growth stages [76]; * $1 €=3.4528 \mathrm{Lt}$

dough stage decreased by $19-22 \%$ (Table 6), when compared with the control treatment, i.e. hard stage maturity.

When harvesting at the hard stage of maturity, the value of spring barley yield mainly depended on the grain value (91-94\% of the spring barley yield value). The grain value at the late milk-early dough stage of maturity was much lower and made $71-77 \%$ of the spring barley biomass value. Comparing spring barley biomass yield value at the late milk-early dough stage of maturity with grain and straw yield value at the hard stage of maturity, it was determined that it was by $12-19 \%$ lower (Table 7 ). 


\begin{tabular}{|c|c|c|c|c|}
\hline \multirow{3}{*}{ Growth stage } & \multirow{3}{*}{ Production } & \multicolumn{3}{|c|}{ Yield value [Lt ha-1] ${ }^{*}$} \\
\hline & & \multicolumn{3}{|c|}{ Year } \\
\hline & & 1997 & 1998 & 1999 \\
\hline \multirow[t]{2}{*}{ Late milk-early dough } & Biomass for silage & 707.00 & 857.65 & 663.91 \\
\hline & Grain + straw & 879.42 & 982.35 & 786.49 \\
\hline \multirow[t]{2}{*}{ Hard } & Grain & 796.80 & 921.60 & 736.00 \\
\hline & Straw & 82.62 & 60.75 & 50.49 \\
\hline
\end{tabular}

Table 7. Value of spring barley yield at two growth stages [76]; * $1 €=3.4528 \mathrm{Lt}$

Analyzing the economical effect of different technologies, it was determined that the profit increased when harvesting spring barley at the late milk-early dough stage of maturity compared to the hard stage of maturity. In 1997 the profit increased by $22.7 \%$, in 1998 by 61.8 $\%$ and in 1999 by $61.9 \%$, respectively (Table 8). The larger profit and smaller costs influenced the larger productive profitability, which increased 1.6 times in 1997, 2.1 times in 1998 and 2.0 times in 1999 while harvesting spring barley at the late milk-early dough stage of maturity [76].

\begin{tabular}{|c|c|c|c|c|c|c|}
\hline \multirow{3}{*}{ Growth stage } & \multicolumn{3}{|c|}{ Profit [Lt ha-1]* } & \multicolumn{3}{|c|}{ Profitability [\%] } \\
\hline & \multicolumn{6}{|c|}{ Year } \\
\hline & 1997 & 1998 & 1999 & 1997 & 1998 & 1999 \\
\hline Late milk-early dough & 47.75 & 183.25 & 59.18 & 7.2 & 27.2 & 9.8 \\
\hline Hard & 38.91 & 113.22 & 36.55 & 4.6 & 13.0 & 4.9 \\
\hline
\end{tabular}

Table 8. Profit and profitability of spring barley harvested at two growth stages [76]; * $1 €=3.4528 \mathrm{Lt}$

Economical calculations show that costs on the average were $819.9 \mathrm{Lt} \mathrm{ha}^{-1}$ and production value was $882.8 \mathrm{Lt} \mathrm{ha}^{-1}$, when spring barley were grown according to conventional farming technology. Therefore, the average profit was $61.9 \mathrm{Lt} \mathrm{ha}^{-1}$, and profitability $7.7 \%$. When spring barley was grown according to alternative technology, the costs were $646.1 \mathrm{Lt} \mathrm{ha}^{-1}$, while yield value, profit and profitability were $742.9 \mathrm{Lt} \mathrm{ha}^{-1}, 96.7 \mathrm{Lt} \mathrm{ha}^{-1}$ and $15.0 \%$ respectively. Other authors [78] determined analogous value of spring barley yield 771-846 Lt ha-1 according to economical evaluation of crop technologies. Economical evaluation of technologies for spring barley growth and harvest determined that the alternative farming technology - harvesting spring barley at the late milk-early dough stage of maturity -is more effective. Compared with the conventional farming technology, costs decreased by $21.2 \%$, profit and profitability increased 1.5 and 1.9 times, respectively. The economical efficiency of the spring barley growth technologies directly depended on the dry matter yield. Linear relationships between spring barley yield and costs and between the yield and received profit were recognized (Figure 13). With the increase of the dry biomass yield of spring barley by $1 \mathrm{t} \mathrm{ha}{ }^{-1}$, growing costs decreased on the average by $50 \mathrm{Lt} \mathrm{ha}^{-1}$ and the received profit increased by $24 \mathrm{Lt} \mathrm{ha}^{-1}$ [76]. Additionally, the 
alternative technology of spring barley growth and harvest reduces weed seed spreading and weediness of the future crop.
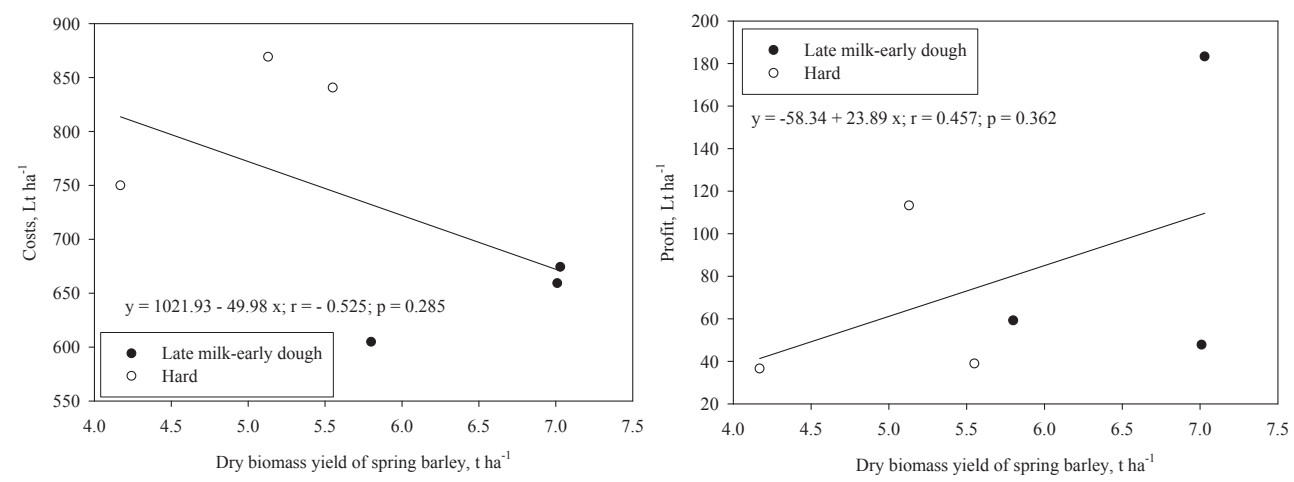

Figure 13. Costs and profit of spring barley technology depending on dry biomass yield $(1 €=3.4528 \mathrm{Lt})$ [76]

\section{Conclusion}

Spring barley agrophytocenosis on separate experimental plots was distinguished for different weed infestation: 395 weeds $\mathrm{m}^{-2}$ and $255 \mathrm{~g} \mathrm{~m}^{-2}$ air-dry biomass of weeds in 1997, 122 weeds $\mathrm{m}^{-2}$ and $98 \mathrm{~g} \mathrm{~m}^{-2}$ in 1998 and 135 weeds $\mathrm{m}^{-2}$ and $19 \mathrm{~g} \mathrm{~m}^{-2}$ in 1999.

Analyzing seed rain of all weed species in spring barley agrophytocenosis, there were established 4543 seeds $\mathrm{m}^{-2}$ in 1997, 2753 seeds $\mathrm{m}^{-2}$ in 1998 and 821 seeds $\mathrm{m}^{-2}$ in 1999 . Weed seed rain was dependent on weed dry weight $r=0.842^{* *}$ and on weed density $r=0.686^{*}$. Consequently, it is very important to minimize accumulated weed biomass in the crop by weed control means before ripening and dispersal; new weed seeds build the soil weed seedbank and further field weediness.

Weed seed rain during vegetation non-linearly depended on active air temperature sum $\mathrm{r}^{2}=$ $0.528^{* *}, 0.538^{*}, 0.119^{*}$; on rainfall $\mathrm{r}^{2}=0.512^{* *}, 0.418^{*}, 0.136^{*}$ and on sunlight duration $\mathrm{r}^{2}=0.567^{* *}$, $0.608^{* *}, 0.155^{*}$. Increasing sum of active air-temperatures and sunlight duration increased weed seed rain by $12-54 \%$ and $14-51 \%$, respectively. In contrast to the air temperatures and sunlight, rainfall inhibited weed seed rain by $16-57 \%$.

Weed seed rain in spring barley agrophytocenosis began at the stem elongation stage and gradually increased until hard stage of maturity. At medium milk stage of maturity, 6-23\% weed seeds were dispersed out and at late milk-early dough stage of maturity, $27-42 \%$ of weed seeds were dispersed. When harvesting cereal at milk or late milk-early dough stage of maturity, non-mature weed seeds are taken from the field together with crop yield and did not infest the soil. When harvesting cereals at medium milk stage of maturity and at late milkearly dough stage of maturity, $77-94 \%$ and $58-73 \%$, of new weed seeds are removed from the 
field, respectively. Accordingly, it helped to control weed seed dispersal and potential weediness of future crops.

Growing and developing spring barley gradually accumulated dry biomass and metabolizable energy that reached the largest amount at milk and late milk-early dough stages. At later stages of spring barley maturity, yield and amount of metabolizable energy in spring barley decreased. Spring barley whole-plant dry matter yield at late milk-early dough maturity stage reached $7.03 \mathrm{t} \mathrm{ha}^{-1}$ and $5.80 \mathrm{t} \mathrm{ha}^{-1}$ accumulating $68.0 \mathrm{Gj} \mathrm{ha}^{-1}$ and $50.1 \mathrm{Gj} \mathrm{ha}^{-1}$ of metabolizable energy, respectively.

Alternative cereal harvesting (late milk-early dough stage of maturity, when grain humidity is $38-45 \%$ ) is promising. Harvesting of the largest crop yield could make it be possible to reduce the price of concentrated forage as well as to decrease weediness. By making whole-plant silage or haylage from cereals at late milk-early dough stage of maturity, more than $20 \%$ greater dry matter yield could be harvested.

Harvesting spring barley at the late milk-early dough growth stage helps to avoid expensive combining, grain and straw managing. Comparing these alternative and conventional technologies economically, it was established that using alternative technology, costs decreased by $21 \%$, profit increased 1.5 times and profitability increased 1.9 times.

\section{Acknowledgements}

We would like to thank Mrs. Vilma Pilipavičienè for her help in English paper corrections.

\section{Author details}

Vytautas Pilipavičius*

Address all correspondence to: vytautas.pilipavicius@asu.lt

Aleksandras Stulginskis University, Institute of Agroecosystems and Soil Sciences, Lithuania

\section{References}

[1] Pilipavičius V. Vasarinių miežių (Hordeum vulgare L.) derliaus kaupimosi ir piktžolių sẻklų byrëjimo dinamika / Dynamics of spring barley (Hordeum vulgare L.) yield accumulation and of weed seed rain. Daktaro disertacija / dr. disertation. Kaunas-Akademija: LZUU, 2000. 102. 
[2] Pilipavičius V. Preventive weed control in lower input farming system. In: $5^{\text {th }}$ EWRS Workshop on Physical Weed Control, 2002, Pisa, Italy. 46-56.

[3] Ciuberkis S. The spreading of weed seeds in the fields of crop rotation. In: Challenges for Weed Science in a Changing Europe: $9^{\text {th }}$ EWRS Symposium, 1995, Budapest, Hungary. 161-165.

[4] Pilipavičius V. Herbicides in winter wheat of early growth stages enhance crop productivity. In: Herbicides- properties, synthesis and control of weeds. Edited by Mohammed Naguib Abd El-Ghany Hasaneen. Rijeka: InTech; 2012. p471-492. ISBN 978-953-307-803-8. Available from: http://www.intechopen.com/articles/show/title/ herbicides-in-winter-wheat-of-early-growth-stages-enhance-crop-productivity

[5] Fawcett RS, Slife FW. Effects of 2,4-D and Dalapon on weed seed production and dormancy. Weed Science 1978; 26(6) 543-547.

[6] Meinlschmidt E., Karch K. Einfluß reduzierter Herbizidendosen auf Unkrautunterdrückung und Samenproduktion. Journal of Plant Diseases and Protection 1994; Sp.iss.XIV 373-380.

[7] Pedersen JO., Rasmussen IA. The influence of herbicides on weed seed production. In: Side effect of Pesticides - Weeds: $7^{\text {th }}$ Danish Plant Protection Conference 1993; 73-83.

[8] Leguizamon ES., Roberts HA. Seed production by an arable weed community. Weed Research 1982; 22(1) 35-39.

[9] Pilipavičius V. Three- year assessment of weed dynamics in herbicide-free barley crop: a field study. Žemdirbystè-Agriculture 2006; 93(3) 89-98.

[10] Hallberg GR. Pesticides pollution of groundwater in the humid United States. Agriculture, Ecosystems \& Environment 1989; 26(3-4) 299-367.

[11] Wacker P. Bekämpfung von Unkräutern bei der Getreideernte. Landtechnik 1989; 6 215-219.

[12] Pilipavičius V. Weed spreading regularity and adaptivity to abiotical factors. Summary of the review of scientific works presented for dr. habil. procedure: Biomedical sciences, agronomy. Kaunas-Akademija: Lithuanian university of agriculture, 2007. 30.

[13] Zadoks JC., Chang TT., Konzak CF. A decimal code for the growth stages of cereals. Weed Research 1974; 14 415-421.

[14] Meier U. Growth Stages of Mono-and Dicotyledonous Plants. BBCH-Monograph, 1997. 572.

[15] Wilson RF., Wilkins RJ. An evaluation of laboratory ensiling techniques. Journal of the Science of Food and Agriculture 1972; 23(3) 377-385. 
[16] Nauman C., Bassler R. Die chemische Untersuchungvon Futtermitteln. Methodenbuch Band III, VDLUFA. Verl. Darmstadt. 1993, 1, 2, 3, 4, 5, 6, 8, Anhang, 1-7.

[17] Naumann C., Bassler R. Bestimmung der Netto-Energie-Laktation (Schatzmethode) Gasbildung nach Hohenheimer Futterwerttest. Die chemische Untersuchung von Futtermitteln. Metodenbuch III, 2 Erganzungslieferung. VDLUFA. Verl. Darmstadt. 1988, 25.1, 1-8.

[18] Rabotnov SA. Методы изучения семеного размножения травянистых растений в сообществах. Полевая геоботаника. Москва-Дениниград; 1960. р20-39.

[19] Moss SR. The production and shedding of Alopecurus myosuroides Huds. seeds in winter cereals crops. Weed Research 1983; 23 45-51.

[20] Stancevičius A., Girkutė A. Piktžolių sẻklų byrẻjimo dinamika javų pasèliuose. LŽŪA mokslo darbai: Žemès ūkio intensyvinimas 1972; 28 25-34.

[21] Basalykas A., Bieliukas K., Chomskis V. (1958). Lietuvos TSR fizinė geografija / Physical geography of Lithuania. Vilnius: Mokslas; 1958.

[22] Naginė V., Skrebutenienė I., Malunavičienė V. Mechanizuotų agroserviso darbų ikkainiai. Pagrindinio žemès dirbimo darbai. Vilnius: Darbo ekonomikos ir mokymo metodikos tarnyba; vol.31. 2004.

[23] Naginè V., Skrebutenienė I., Malunavičienė V. Mechanizuotų agroserviso darbų ikainiai. Pasèlių priežiūra ir šienapjūtės darbai. Vilnius: Darbo ekonomikos ir mokymo metodikos tarnyba; vol.33. 2004.

[24] Naginè V., Skrebutenienė I., Malunavičienė V. Mechanizuotų agroserviso darbų ikainiai. Derliaus nuemimo darbai. Vilnius: Darbo ekonomikos ir mokymo metodikos tarnyba; vol.35. 2004.

[25] Tarakanovas P. Nauja kompiuterinès programos versija bandymo duomenų apdorojimo dispersinès analizès metodu / A new version of the computer programme for trial data processing by the method of analysis of variance. Žemdirbystè-Agriculture $1997 ; 60$ 197-213.

[26] Tarakanovas P. Statistinių duomenų apdorojimo programų paketas Selekcija. Akademija: LŽI; 1999. 57.

[27] Spss Science: SigmaStat ${ }^{\circledR}$ Statistical Software Version 2.0. User's Manual. USA, 1997.

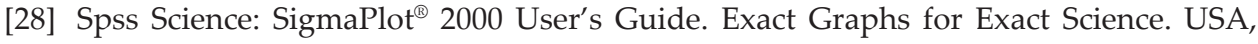
2000. 435.

[29] Pilipavičius V. Competition of weeds and spring barley in organic and conventional agriculture. Vagos 2005; 68(21) 30-43.

[30] Zwerger P. Zur Samenproduktion der Acker-Kratzdistel (Cirsium arvense (L.) Scop.). Journal of Plant Diseases and Protection 1996; Sp.iss.XV 91-98. 
[31] Pilipavičius V. Ausfall von Unkrautsamen in Abhängigkeit von Unkrautbiomasse und Unkrautdichte. Journal of Plant Diseases and Protection 2002; Sp.iss.XVIII 239-245.

[32] Pilipavičius V. The Influence of Stellaria media (L.) Vill., Sonchus asper (L.) Hill., Capsella bursa-pastoris (L.) Medik. plants air-dry weight and density on their seed rain in the spring barley crop. Žemdirbystè-Agriculture 2001; 76 38-46.

[33] Kohout V. Herbologie / Weed science. Plevele a jejich regulace / Weeds and their control. Praha: Czech university of agriculture; 1996, 116.

[34] Pilipavičius V., Lazauskas P. Regulierung der Unkrautsamenverbreitung im Getreide. Journal of Plant Diseases and Protection 2000; Sp.iss.XVII 469-472

[35] Blackshaw RE., Rode LM. Effect of ensiling and rumen digestion by cattle on weed seed viability. Weed Science 1991; 39 104-108.

[36] Grigas A. Daugiamečių žolių sẻklinių pasėlių ir sẻklų piktžolètumas bei piktžolių sẻklų gyvybingumo išsilaikymas. LŽMTI mokslo darbai 1980; 25 105-117.

[37] Grigas A. Issledovanie sochranenija ziznessposobnosti semian sornych rastenii. In: Proceedings Zashchita rastenii v respublikach pribaltiki i Belorusii, Chiast I. 1981, Dotnuva - Akademija, Lithuania, 113-114.

[38] Grigas A., Smulkienė B. Piktžolių sẻklų gyvybingumas, skirtingą laiką joms išbuvus silose. LŽMTI mokslinių straipsnių rinkinys: Agronomija 1989; 63 93-101.

[39] Sarapatka B., Holub M., Lhotska M. The effect of farmyard manure anaerobic treatment on weed seed viability. Biological Agriculture and Horticulture 1993; 10 1-8.

[40] Grigas A., Smulkienė B. Piktžolių sẻklų gyvybingumas, skirtingą laiką joms išbuvus skystame méšle. LŽMTI mokslinių straipsnių rinkinys: Agronomija 1989; 63 83-92.

[41] Tereshchuk V. Sources of weed infestation of agricultural land and the problems of weed control. In: Challenges for Weed Science in a Changing Europe: $9^{\text {th }}$ EWRS Symposium, 1995, Budapest, Hungary. 135-141.

[42] Grigas A. Sėklų, perëjusių galviju virškinamaji traktą gyvybingumas. LŽMTI mokslo darbai: Agronomija 1987; 35 165-175.

[43] Pilipavičius V. Piktžolių sẻklų byrëjimo priklausomumas nuo meteorologinių faktorių / Dependence of weed seed falling on meteorological factors, precipitation and sunlight duration. Vagos 2002; 53(6) 17-21.

[44] Gmira N., Douira A., Bouhache M. Ecological grouping of Solanum elaeagnifolium: a principal weed in the irrigated Tadla plain (central Moroko). Weed Research 1998; 38 87-94. 
[45] Thomas AG., Lefkovitch SL., Woo SL., Bowes GG., Peschken DP. Effect of temperature on germination within and between diploid and tetraploid populations of Matricaria perforata Merat. Weed Research 1994; 34 187-198.

[46] Benvenuti S., Macchia M., Miele S. Light, temperature and burial depth effects on Rumex obtusifolius seed germination and emergence. Weed Research 2001; 41 177-186.

[47] Harris SM., Doohan DJ., Gordon RJ., Jensen KIN. The effect of thermal time and soil water on emergence of Ranunculus repens. Weed Research 1998; 38 405-412.

[48] Röhring M., Stützel H. Canopy development of Chenopodium album in pure and mixed stands. Weed Research 2001; 41 111-128.

[49] Dakheel AJ., Radosevich SR., Barbour G. Effects of temperature and moisture on growth, interference and photosyntesis of Bromus tectorum and Taeniatherum asperum. Weed Research 1994; 34 11-22.

[50] Pilipavičius V. Piktžolių sẻklų kiekis grūduose priklausomai nuo vasarinių miežių brandos tarpsnio / Weed seed getting into grain according to spring barley maturity stage. Vagos 2006; 71(24) 51-57.

[51] Svihra J., Talapka S. Rastovo-produkcny a akumulacny proces vybranych odrod jarneho jacmena. Rostlina vyroha 1995; 41 249-253.

[52] Striegl M. Faktory ovlivnujici tvorbu biomasy u jarnich obilnin. Rostlina vyroba 1982; 28 363-370.

[53] Petr J., Cierny V., Gruska L. Formirovanije urozaja osnovnych selskochozeistvennych kultur. Moskva. 1984.

[54] Korneva EJ., Davidov BN., Koskin EI. Optimizacija srokov uborki jacmenia dlia briketirovanija. In: Biologiceskie osnovy povyshenija prodnktivnosti selskochozeistvennych kultur: proceedings. 1984, Moskva. 96-99.

[55] Majdoub A., Mehouachi M., Yahyaoui A., Rahmani L. Chemical composition and nutritive value of three barley cultivars grown under the semi-arid conditions of northwestern Tunisia. Barley and Wheat Newsletter, ICARDA 1994; 13 15-19.

[56] Repka J., Rimar J., Lorencik L. Vplyv podneho typu na produkcne procesy a produkciu porastov polnych plodin. Rostlina vyroba 1978; 24 1235-1245.

[57] Petr J. Weather and yield. Praha: Developments in crop science 20, 1991.

[58] Mašauskienė A., Leistrumas K., Dovydaitis V. Miežių ir avižų bei vikių ir avižų mišinio derliaus bei cheminès sudèties dinamika pieninès, pieninės-vaškinės, vaškinès ir kietosios brandos fazėse. LŽMTI mokslo darbai: Agronomija 1982; 28 126-132.

[59] Pilipavičius V. The effect of harvest growth stage on the yield, chemical composition and metabolizable energy of spring barley. Scientia Agriculturae Bohemica 2004; 35 41-51. 
[60] Pilipavičius V. Vasarinių miežių sausųjų medžiagų ir apykaitos energijos derliaus kaupimosi dinamika / Dynamics of spring barley dry matter and metabolic energy yield accumulation. Žemdirbystè - Agriculture 2000; 72 91-102.

[61] Baier J. Obsah zivin v susine ozime psenice v probehu ontogeneze. Rostlinna vyroba $1986 ; 32$ 459-471.

[62] Ayub M., Dewi IAP., Tanveer A. Forage yield and quality of barley as influenced by nitrogen application and harvest dates. Pakistan Journal of Biological Sciences. 1999; 2(4) $1278-1282$.

[63] Kupka J., Novak V., Lipavsky J. Dynamika obsahu fosfoni a tvorba susiny v ontogenezi jarniho jecmene. Rostlina vyroba 1977; 23 741-744.

[64] Pettersson R. Above-ground growth dynamics and net production of spring barley in relation to nitrogen fertilization. Swedish Journal of Agricultural Research 1989; 19 135-145.

[65] Mikulionienė S., Stankevičius, R. Zootechninė pašarų analizė ir jų energetinè vertè, $2^{\text {nd }}$ edition. Akademija: LZUU; 2003.

[66] Martin J., Seibold R. DLG-Futterwerttabellen. Wiederkäuer. 7., erweiterte und überarbeitete Auflage. Universität Hohenheim. Frankfurt am Main: DLG-Verlag; 1997.

[67] Pilipavičius V. Spring barley over-ground biomass digestibility in vitro. Veterinarija ir Zootechnika 2012; 58(80) 65-69.

[68] Pilipavičius V. Whole plant silage nutritive value from spring barley of different maturity. Veterinarija ir Zootechnika 2007; 37(59) 61-66.

[69] Nykänen A., Jauhiainen L., Rinne M. Biomass production and feeding value of whole-crop cereal legume silages. Agronomy Research 2009; 7(Special issue II) 684690.

[70] Statistics Lithuania (2011). Statistikos departamentas prie LRV (2011), M5010302: Agricultural crops in country / Žemès ūkio augalai šalyje. http://db1.stat.gov.lt/statbank/default.asp?w=1229/ (accessed 30 August 2012).

[71] Šapolienė A. Agriculture in Lithuania 2003. Vilnius: Statistikos departamentas prie Lietuvos Respublikos Vyriausybes; 2004. 105.

[72] Rudys E. Lietuvos žemės ūkio ekonominė apžvalga 1993-1997 / Economical review of Lithuanian agriculture 1993-1997. Vilnius: LRZUM, LAEI. 1999. 136.

[73] Nedzinskienè T., Vegys R., Dabkevičiūtė H., Dabkevičienė D. Vasarinių miežių auginimas pagal intensyvią technologiją priesmèlio dirvose. LŽI mokslinių straipsnių rinkinys: Agronomija 1993; 72 89-98.

[74] Surkus J., Semaska J., Semaskiene R. Kompleksiškas pesticidų ir karbamido naudojimas miežiuose. Zemdirbyste-Agriculture 1999; 68 90-107. 
[75] Edwards RA., Donalson E., MacGregor AW. Ensilage of whole-crop barley. I-Effects of variety and stage of growth. Journal of the Science of Food and Agriculture 1968; 19 656-660.

[76] Pilipavičius V., Makutėnienė D., Makutėnas V. Economical evaluation of spring barley yield at different stages of maturity. Journal of Plant Diseases and Protection 2006; Sp.iss.20 867-873.

[77] Swinton SM. Economics of site-specific weed management. Weed Science 2005; 53 259-263.

[78] Kinderiene I. Energy and economic comparison of measures designed for erosion reduction on hilly soils. Zemdirbyste - Agriculture 2005; 89 39-52.

[79] Séralini G.-E., Clair E., Mesnage R., Gress S., Defarge N., Malatesta M., Hennequin D., Spiroux de Vendōmois J. Long term toxicity of a Roundup herbicide and a Roundup-tolerant genetically modified maize. Food and Chemical Toxicology 2012; http://dx.doi.org/10.1016/j.fct.2012.08.005 
